\title{
Bank Deregulation and Racial Inequality in America
}

\author{
Ross Levine, Alexey Levkov, and Yona Rubinstein*
}

\section{October 2012}

\begin{abstract}
We use the cross-state, cross-time variation in bank deregulation across the U.S. states to assess how improvements in banking systems affected the labor market opportunities of black workers. Bank deregulation from the 1970s through the 1990s improved bank efficiency, lowered entry barriers facing nonfinancial firms, and intensified competition for labor throughout the economy. Consistent with Becker's (1957) seminal theory of racial discrimination, we find that deregulation-induced improvements in the banking system boosted blacks' relative wages by facilitating the entry of new firms and reducing the manifestation of racial prejudices in labor markets.
\end{abstract}

Keywords: Discrimination, Imperfect Competition, Banks, Regulation

JEL Classification Codes: J7, J31, D43, D3, G21, G28

*Levine: Haas School of Business at the University of California-Berkeley, the Milken Institute, and the NBER; Levkov: Federal Reserve Bank of Boston; Rubinstein: London School of Economics, the CEPR, and IZA. We thank seminar participants at Brown University, the Bank of Israel, the Federal Reserve Bank of New York, Harvard University, and the NBER Workshop on "Income Distribution and Macroeconomics." We also thank Daron Acemoglu, Gary Becker, Roland Benabou, Steve Durlauf, Ken Chay, Raquel Fernandez, Glenn Loury, and Ivo Welch for very useful discussions. We thank Kerwin Charles and Jonathan Guryan for sharing their data and the Charles G. Koch Charitable Foundation for providing financial support.The views expressed here are solely those of the authors and do not necessarily reflect official positions of the Federal Reserve Bank of Boston or the Federal Reserve System. 
Financial systems shape economic opportunities through direct and indirect channels. For example, the degree to which financial systems ameliorate information and transactions costs influences the nature of credit rationing, the cost of raising capital, and hence the barriers to starting or expanding businesses. Furthermore, more efficient financial systems can lower entry barriers in nonfinancial industries, fostering the entry of new more efficient firms with potentially large effects on the demand for labor and the competitiveness of labor markets. For example, Beck, Levine, and Levkov (2010) show that more efficient financial systems reduce unemployment and income inequality among salaried workers in nonfinancial industries. Thus, by affecting the entry of new firms and labor market conditions, finance can shape the economic opportunities available to individuals-even people who never receive a loan or issue a security.

In this paper, we contribute to research on how finance shapes economic opportunities by evaluating the impact of a deregulation-induced improvement in the U.S. banking system on racial inequality. Research documents that black workers earn less than their white counterparts after controlling for differences in education and experience. Yet, researchers have neither determined the degree to which this racial wage gap reflects differences in unobserved skills or racial discrimination, whereby blacks are paid less than identically productive whites, nor have researchers examined the role of financial sector policies in influencing racial wage inequality. We provide the first assessment of how the financial system affects the racial wage gap; and, in conducting this assessment we provide novel evidence on the role of racial discrimination in influencing blacks' relative wages.

Our research strategy is structured by Becker's (1957) seminal theory of racial discrimination, which holds that (1) taste-based discrimination, the disutility that white employers attach to hiring black workers, can produce an enduring racial wage gap and (2) lowering barriers that impede the entry of new firms can reduce this racial wage gap between identically productive workers. Becker argues that with lower entry barriers, firms with less of a taste for discrimination can enter the market and initiate profitable operations by hiring equally productive black workers at lower wage rates than their white counterparts, boosting the relative demand for black workers and reducing the racial wage gap. Becker did not argue that new firms would reduce racial prejudices. Rather, he argued that lower entry barriers would erode the manifestation of racial prejudices on labor market outcomes. Accordingly, Becker's (1957) model predicts that lower entry barriers will reduce the racial wage gap but only if racial prejudices had been contributing to the black-white wage differential. If racial attitudes 
were not depressing blacks' relative wages, then reducing entry barriers will not reduce the manifestation of those prejudices on the racial wage gap within the context of Becker's taste-based theory of discrimination.

Thus, to assess the impact of finance on racial inequality, we build both on research in finance and labor economics. From finance, Black and Strahan (2002), Cetorelli and Strahan (2006), Kerr and Nanda (2009), show that policy-induced improvements in the U.S. banking system lowered entry barriers in nonfinancial industries and intensified product market competition. From labor, Becker (1957) argues that intensified product market competition will reduce the manifestation of racial prejudices in labor markets. We test whether regulatory-induced improvements in banking system efficiency reduced the racial wage gap by intensifying product market competition in a manner consistent with Becker's (1957) taste-based theory of discrimination.

Specifically, we use interstate and intrastate bank deregulation across the U.S. states to identify an exogenous lowering of entry barriers impeding the entry of nonfinancial firms, and evaluate the impact on the racial wage gap while differentiating among U.S. state economies with stronger and weaker racial prejudices. From the mid-1970s to 1994, individual states relaxed restrictions on the entry of banks from other states and the branching of banks within states, boosting bank competition, efficiency, and the effectiveness of credit allocation (Jayaratne and Strahan, 1998; Hubbard and Palia, 1995). These improvements in the banking industry lowered barriers to the entry of new firms throughout the economy (Black and Strahan, 2002; Kerr and Nanda, 2009), spurring competition in nonfinancial industries. Thus, we evaluate whether bank deregulation reduced a state's overall racial wage gap by spurring the entry of new firms (new incorporations), which is the key mechanism suggested by the tastebased theory of discrimination.

To assess whether bank deregulation reduced racial inequality by reducing the impact of racial prejudices on labor markets, we use several state-specific measures of racial attitudes. First, from the 1970 U.S. census, we compute the predicted rate of racial intermarriage based on individual and state characteristics. We interpret the difference between the predicted rate of intermarriage and the actual rate as positively related to the taste for discrimination. Although imperfect, this racial bias index captures decisions made far before our sample period since the 1970 census contains the accumulated stock of marriages in 1970 and we begin our analyses in 1976. Furthermore, we confirm the results using survey-based measures of racial attitudes from 
Charles and Guryan (2008). ${ }^{1}$

We find that bank deregulation that intensified product market competition substantially reduced racial wage discrimination by ameliorating the manifestation of racial prejudices in labor markets. We first find that bank deregulation increased the rate of new incorporations across states with different values of the racial bias index. Dynamically, the impact of deregulation on the rate of new incorporations grows over time. Second, bank deregulation increased blacks' relative wage rates, but only in "high racial bias" states. In states with above the median level of the racial bias index, deregulation eliminated about one-third of the initial racial wage gap after five years. Furthermore, the dynamic impact of deregulation on blacks' relative wages mirrors that of deregulation on new incorporations, with blacks' relative wages rising for many years following bank deregulation. Third, blacks' relative wages are positively associated with the rate of new incorporations in high racial bias states. Thus, while bank deregulation boosted the rate of new incorporations in both high and low racial bias, there is a positive association between blacks' relative wages and both bank deregulation and new incorporations only in high racial bias states.

Moreover, the two-stage least squares results indicate that an exogenous lowering of entry barriers triggered by bank deregulation only boosted blacks' relative wages in states with a sufficiently high taste for discrimination. Using inter- and intrastate bank deregulation as instrumental variables to identify exogenous shocks to the rate of new incorporations, we find that increases in the rate of new incorporations only reduced the racial wage gap in high racial bias states, such that a ten percent increase in the rate of new incorporations reduced the black-white wage differential by 2.5 percent.

The results are robust to several potentially confounding influences. First, one might be concerned that these results simply reflect the observation that bank deregulation exerted a disproportionately positive effect on the poor (Beck, Levine, and Levkov, 2010) and the poor are disproportionately black. But, three observations suggest that this is not the case: (a) bank deregulation increased blacks' relative wages only in high racial bias states, but there is not evidence the income inequality fell more in high racial biase states, (b) the results hold when conditioning on occupation,

\footnotetext{
${ }^{1}$ Our work complements Charles and Guryan's (2008) study of the relation between racial prejudices and blacks' relative wages. Using state-level survey measures of racial prejudices to gauge relative demand for black workers and the share of black workers in the labor force, they provide the first empirical support for Becker's (1957) hypothesis that a stronger taste for discrimination by the marginal firm reduces blacks' relative wage rates. Rather than evaluating the relation between racial prejudices at the margin and relative wages, we examine the impact of changes in competition on changes in relative wage rates, while distinguishing states by the taste for discrimination.
} 
suggesting that blacks' relative wage rose in higher- and lower-income jobs, and (c) blacks' relative wages rose across the full distribution of relative wage rates. Second, deregulation could have shifted blacks into higher paying occupations and industries rather than boosting blacks' relative wages. Or, deregulation might have disproportionately boosted wage rates with a comparatively high proportion of black workers, not by reducing the manifestation of racial prejudices. But, we find that deregulation boosted blacks' wages relative to white workers in the same industry and occupation. Third, bank deregulation could have reduced labor force participation by low ability black workers and thereby boosted observed relative wage rates. However, we find that bank deregulation increased the relative working hours of black workers in high racial bias states, consistent with the interpretation that intensified competition boosted the relative demand for black workers. Fourth, bank deregulation could trigger changes in the skill composition of the labor force through the selection of workers into the labor force, interstate migration, and changes in self-employment (Butler and Heckman, 1977; Mulligan and Rubinstein, 2008). We find no evidence that bank deregulation substantively affected the relative skill composition of black workers. Fifth, bank deregulation could have changed the prices of unobserved skills in which average black and white workers are differentially endowed. Following Juhn, Murphy, and Pierce (1991), however, we find that bank deregulation improved black workers' location throughout white workers' residual wage distribution, indicating that competition boosted blacks' relative wages in particular, not the relative wages of comparatively low income workers in general. Sixth, there might be concerns that states with a high degree of racial bias converge toward low racial bias states, or that blacks' relative wages increase over time, or that business cycles somehow account for the findings. But, the results hold after accounting for state and year fixed effects, which control for all time-varying national influences, as well as state-specific factors.

Our major contribution is showing that exogenous improvements in the functioning of banks substantively enhanced the economic opportunities of an historically disadvantaged group. Financial deregulation reduced racial inequality by diminishing the impact of racial prejudices on labor market opportunities. We also contribute to a large literature on racial discrimination. ${ }^{2}$ We provide the first evaluation of whether

\footnotetext{
${ }^{2}$ We are obviously not the first to examine competition and discrimination. Becker (1957), Shepard and Levin (1973), and Oster (1975) compare market concentration and relative wage rates across industries, obtaining mixed results. Ashenfelter and Hannan (1986) find a negative association between market concentration and the share of female employees across several banking markets in Pennsylvania and New Jersey. Heywood and Peoples (1994) and Peoples and Talley (2001) find that the deregulation of trucking increased the relative wage rates of black workers. Black and Strahan
} 
the impact of an exogenous lowering of entry barriers facing nonfinancial firms on blacks' relative wages varies positively with the economy's taste for discrimination. That is, we not only assess whether lowering entry barriers increases blacks' relative wages in general, we examine whether it increases blacks' relative wages only in those environments in which the taste-based theory of discrimination suggests that competition will enhance blacks' labor market opportunities. Our results are fully consistent with the central implication of the taste-based theory of discrimination: lowering entry barriers so that new firms can contest and compete with existing firms diminishes the manifestation of racial prejudices on labor markets.

\section{Bank Deregulation and New Firm Entry}

\subsection{Bank Branch Deregulation}

The history of geographic restrictions on banking-along with standard econometric evidence-supports a key requirement of our estimation strategy: Namely, that bank deregulation is exogenous to competition and blacks' labor market outcomes. As described by White (1982), geographic restrictions on banking protected local banks from competition for much of the $20^{t h}$ century. By protecting inefficient banks, geographic restrictions created a powerful constituency for maintaining these regulations.

In the last quarter of the $20^{\text {th }}$ century, however, technological, legal, and financial innovations diminished the economic and political power of banks benefiting from geographic restrictions. In particular, a series of innovations lowered the costs of using distant banks. This reduced the monopoly power of local banks and weakened their ability and desire to lobby for geographic restrictions. For example, the invention of automatic teller machines (ATMs), in conjunction with court rulings that ATMs are not bank branches, weakened the geographical link between banks and their clientele. Furthermore, the creation of checkable money market mutual funds made banking by mail and telephone easier, thus further weakening the power of local bank monopolies. Finally, the increasing sophistication of credit scoring techniques, improvements in information processing, and the revolution in telecommunications reduced the informational advantages of local bankers, especially with regards to small and new firms.

These national developments interacted with preexisting state characteristics to

(2001) find that bank deregulation increased competition between banks, disproportionately reducing the rents paid to male workers relative to female bank employees. Within manufacturing, Black and Brainerd (2004) find that globalization intensified competition and thereby reduced the gender wage gap. 
shape the timing of bank deregulation across the states. As shown by Kroszner and Strahan (1999), deregulation occurred later in states where potential losers from deregulation (small, monopolistic banks) were financially stronger and had a lot of political power. On the other hand, deregulation occurred earlier in states where potential winners of deregulation (small firms) were relatively numerous. Most states deregulated geographic restrictions on banking between the mid-1970s and 1994, when the Riegle-Neal Act effectively eliminated these restrictions.

Research also indicates that the forces driving bank deregulation were exogenous to competition in the non-financial sector and the racial wage gap. The timing of deregulation was not shaped by new firm formation (Black and Strahan, 2002, Kerr and Nanda, 2009), the strength of labor unions (Black and Strahan, 2001), or the degree of earnings inequality (Beck, Levine, and Levkov, 2010). Moreover, we show below that the racial wage gap does not explain the timing of bank deregulation.

\subsection{Bank Deregulation and New Firm Entry in Non-Financial Sectors}

Deregulation increased competition within the banking sector by making it possible for banks to (a) open branches across markets within a state and (b) open subsidiaries in other states. By increasing competition, deregulation improved bank performance. It reduced interest rates on loans, raised them on deposits, lowered overhead costs, and shrunk the proportion of bad loans (Jayaratne and Strahan, 1998). And, by enhancing the contestability of banking markets, deregulation expedited the development of better techniques for evaluating firms (Hubbard and Palia, 1995).

In boosting banking sector performance, bank deregulation reduced entry barriers facing firms in nonfinancial sectors. Improvements in banking - lower lending rates, better screening of borrowers, etc.-lowered financial barriers facing new firms, intensifying competition in the overall economy. Black and Strahan (2002) find that deregulation helped entrepreneurs start new businesses, with the rate of new incorporations per capita in a state increasing by six percentage points following deregulation. Kerr and Nanda (2009) find that interstate deregulation increased the number of new start-ups by six percentage points and expanded the number of facilities of existing firms by four percentage points. Kerr and Nanda (2009) also find a dramatic increase in both the entry and exit of firms, suggesting that deregulation increased contestability throughout the economy. 


\section{Data}

\subsection{State-level data on deregulation and new firm entry}

The dates of interstate and intrastate bank deregulation are from Kroszner and Strahan (1999) and Amel (2008). Most states removed these geographic restrictions on banking between the mid-1970s and 1994, when they were eliminated by federal legislation. The Annex provides the deregulation dates.

Since the taste-based theory of discrimination focuses on the actual entry of new firms, we use the rate of new incorporations to measure competition. Specifically, we use the log of new business incorporations per capita for each state over the period 1977-1994, where the new incorporations data are from Black and Strahan (2002), who obtain them from Dun and Bradstreet.

\subsection{Generating Relative Residual Wages}

\subsubsection{CPS Samples for the Years 1977 to 2007}

Data on wages and worker characteristics are from the Integrated Public Use Microdata Series (IPUMS) from the U.S. Current Population Survey (CPS, March Supplements for the survey years 1977 to 2007). The CPS March Annual Demographic Supplements provide information on earnings, along with weeks and hours worked in the calendar year preceding the March survey so that the 1991 survey provides information on earnings in 1990. We start in Survey year 1977 because that is when the CPS reports information on each person's state of residence. To enhance comparability and connect our analyses to the literature, we restrict our sample to non-Hispanic white and black adult civilian males between the ages of 18 and 65 during the working year, and exclude persons living in group quarters or with missing data on relevant demographics. Our main wage sample further excludes the self-employed, persons in the military, agricultural, or private household sectors, persons with inconsistent reports on earnings, and individuals with allocated earnings.

We classify the adult population into six educational categories: (i) persons with 0-8 years of schooling completed; (ii) high school dropouts; (iii) high school graduates; (iv) some college; (v) college graduate; and (vi) advanced degree. Potential work experience is constructed as the maximum between zero and age minus years of schooling completed minus seven. In some specifications, we differentiate workers by industry and occupation (144 industries and 262 occupations). 
Wage rates are defined as real annual earnings divided by the product of weekly working hours and annual working weeks. We use the Consumer Price Index to deflate earnings to 2000 dollars. Following Autor, Katz, and Kearney (2008), workers with top coded earnings have their earnings set to 1.5 times the annual top-code. We trim outliers with wages below the 1st percentile and above the 97th percentile of the year-specific distribution of hourly earnings of full-time, full-year workers. This trimming virtually eliminates individuals with top-coded earnings. The results are robust to altering the definition of outliers. Consistent with previous research on bank deregulation, we drop Delaware and South Dakota due to large concentration of credit card banks in these states. The Annex provides more details on the sample.

\subsubsection{Relative residual wages: Framework}

We decompose the black-white wage differential into "explained" and "residual" components, where the residual component is the "racial wage gap." In particular, assume that $\log$ hourly wages for a white individual $i$ in state $s$ at time $t$ can be written as:

$$
W_{i s t}^{W}=X_{i s t} \theta_{t}^{W}+R_{i s t}^{W}
$$

and $\log$ hourly wages for a black individual $i$ in state $s$ at time $t$ can be written as:

$$
W_{i s t}^{B}=X_{i s t} \theta_{t}^{B}+R_{i s t}^{B},
$$

where $X_{\text {ist }}$ represents individual characteristics associated with log hourly wages in state $s$ in year $t$, including Mincerian characteristics, such as education and experience, and state-year fixed effects. The parameters, $\theta_{t}^{W}$ and $\theta_{t}^{B}$, are defined so that $E\left(R_{s t}^{W} \mid X_{s t}^{W}\right)=0$ and $E\left(R_{s t}^{B} \mid X_{s t}^{B}\right)=0$, where $X_{s t}^{W}\left(X_{s t}^{B}\right)$ is the mean $X_{\text {ist }}$ of white (black) workers in state $s$ in year $t$, and $R_{s t}^{W}\left(R_{s t}^{B}\right)$ is the mean value of $R_{i s t}^{W}\left(R_{i s t}^{B}\right)$ across white (black) workers $s$ in year $t$. Thus, the mean wage across white workers in state $s$ in year $t$ is defined as $W_{s t}^{W}=X_{s t}^{W} \theta_{t}^{W}$ and the corresponding value for black workers is $W_{s t}^{B}=X_{s t}^{B} \theta_{t}^{B}$.

We can then define the mean black-white wage differential in state $s$ in year $t$ as:

$$
W_{s t}^{B}-W_{s t}^{W}=\Delta X_{s t} \theta_{t}^{W}+X_{s t}^{B} \Delta \theta_{t}=\Delta X_{s t} \theta_{t}^{W}+R_{B s t},
$$

where $\Delta X_{s t}=X_{s t}^{B}-X_{s t}^{W}, \Delta \theta_{t}=\theta_{t}^{B}-\theta_{t}^{W}$, and $X_{s t}^{B} \Delta \theta_{t}=R_{B s t}^{W}$.

The "explained" component of the black-white wage differential is $\Delta X_{s t} \theta_{t}^{W}$. It 
represents the mean wage differential explained by the mean observed "skill" differential between black and white workers $\Delta X_{s t}$, where these skill differences are valued or "priced" using the returns that the average white worker gets for these skills $\left(\theta_{t}^{W}\right)$.

The "residual" (racial wage gap) component, $X_{s t}^{B} \Delta \theta_{t}$, which we designate as $R_{B s t}$ for simplicity, is that part of the mean black-white wage differential unaccounted for by mean skill differentials. The residual component represents the average wage gap between black and white workers with identical characteristics that emerges because of racial differences in the returns to these characteristics $\left(\Delta \theta_{t}=\theta_{t}^{B}-\theta_{t}^{W}\right)$. Recall, these characteristics include standard, observable Mincerian traits as well as unobservable differences in the average productive characteristics of black and white workers at the state-year level.

Thus, the racial wage gap $\left(R_{B s t}\right)$ captures both the effects of labor market discrimination and unobserved productivity differences between black and white workers. A large literature focuses on identifying the role of these two sources. For example, Neal and Johnson (1996) attribute much of the unexplained gap in wages to differences in cognitive abilities. In this paper we focus on evaluating the effect of competition on labor market discrimination, i.e., the effect of competition on racial differences in the "prices" of skills. We use the differential timing of bank deregulation across states and differences in the taste for discrimination across states to identify the effect of competition on labor market discrimination against black workers.

\subsubsection{Relative residual wages: Estimation}

First we estimate equation (1) separately for each year. Thus, we allow the Mincerian returns to observable skills $\left(\theta_{t}^{W}\right)$ to vary by year. This is crucial because of the the well-documented skill gap between black and white workers. Failure to account for time-varying returns to skills will lead to erroneous estimates of the dynamic pattern of relative wages, potentially biasing our assessments.

Then, employed with $\theta_{t}^{W}$, we compute residual wages $\left(R_{i s t}\right)$ for all workers, white and black:

$$
R_{i s t}=W_{i s t}-\theta_{t}^{W} X_{i s t}
$$

By construction, $R_{s t}$ for white workers equals zero in each state-year. For black workers the average relative residual wage, $R_{B s t}$, can differ from zero.

Since $X_{i s t}$ effectively includes state-year effects (and state-industry-year effects in some specifications), relative residual wages already account for state-year (or state- 
year-industry) effects on white workers' wages, including the effect of banking deregulation on the wage rates of white workers.

By controlling for these wage rate determinants, we account for the impact of bank deregulation on white workers' wages. If bank deregulation affects wages but does not affect labor market discrimination or the unobservable differences in the mean productive characteristics of black and white workers in a state, then we should find no association between deregulation and blacks relative residual wages.

From a methodological perspective, an equivalent approach to this two-step procedure is to run a single wage regression that includes sufficient interaction terms based on race, year, state, and demographics to capture the properties mentioned above. This yields identical results, but the two-step approach is computationally faster.

\subsection{Racial Bias Indexes}

Throughout our analyses, we explicitly account for cross-state differences in the taste for discrimination. This is both novel and essential to drawing accurate inferences because competition should have a larger impact on blacks' relative wages in states with a greater taste for discrimination (all other things equal).

We develop two types of racial bias indexes based on the accumulated stock of racial intermarriage in 1970. We use the 1970 Census to construct information on the rate of racial intermarriage in each state. The Census samples are the largest microdata set containing detailed marriage and demographic information. Our primary sample includes married whites and blacks between the ages of 18 and 65, and excludes couples in which at least one person is living in group quarter or has missing data on race, gender, state of residence, marital status and educational attainment.

The "simple" racial bias index equals the difference between the rate of intermarriage that would exist if married people were randomly matched and the actual intermarriage rate. The random rate equals $2 P *(1-P)$, where $P$ is the proportion of blacks among the married population. Larger values of the simple racial bias index indicate that intermarriage occurs less in practice than if marriage pairings were random. We interpret larger values as (partially) reflecting racial bias.

In the second type of index, we account for other factors that might induce the actual rate of intermarriage to deviate from the random rate. Intermarriage depends on the opportunities for interracial social contacts, so that the relative sizes of the blackwhite populations might independently affect intermarriage (Blau, 1977). Also, since the odds of interethnic unions increase with couples' educational attainment (Massey 
and Denton, 1987; Qian, 1997; Rubinstein and Brenner, 2009), we control for education and age. We estimate the following equation for married couples:

$$
I_{i s}=b H_{i s}+c W_{i s}+d S_{s}+\tau_{i s}
$$

where $I_{i s}$ equals one if couple $i$ in state $s$ is racially mixed and zero otherwise, $H_{i s}$ and $W_{i s}$ are vectors of age and education characteristics for the two spouses respectively, $S_{s}$ are state characteristics, $\tau_{i s}$ is the unexplained component of intermarriage, while $b, c$, and $d$ are coefficients. For state characteristics, we include the random intermarriage rate defined above along with the percentage of blacks among married couples. We experimented with numerous specifications, including and excluding the random intermarriage rate and the percentage of blacks, changing the specification of education and age controls, and conditioning on metropolitan and urban locations. These combinations produce the same conclusions.

From equation (5), we compute the intermarriage racial bias index for each state. Let $\tau_{s}$ equal the average value of $\tau_{i s}$ across couples in state $s$. Recognizing that $\min \left\{\tau_{s}\right\}<0$, we compute the racial bias index as $\widetilde{T}_{s}=-\tau_{s}+\max \left\{\tau_{s}\right\}$, so that $\widetilde{T}_{s}$ equals zero for the state with the largest $\tau_{s}$. We interpret large values as signaling a stronger taste for discrimination. The Annex provides the value of the racial bias index, $\widetilde{T}_{s}$, for each state and the District of Columbia.

The intermarriage racial bias index is positively correlated with survey-based measures of racial prejudice. Table 1 (Panel A) shows that the intermarriage racial bias index is positively related to three survey-based measures of racial prejudice used by Charles and Guryan (2008) in their study of relative wages and racial prejudices: (1) the fraction of whites supporting a law against interracial marriage, (2) the fraction of whites that would not vote for a black president, and (3) the fraction of whites supporting the right to segregate neighborhoods by race.

The intermarriage racial bias index is negatively correlated with blacks' relative wages. Table 1 (Panel B) shows that the intermarriage racial bias index is negatively associated with blacks' relative wage rates in the years prior to deregulation, even when controlling for the supply of blacks in the workforce, suggesting that the racial bias index captures cross-state differences in the relative demand for black workers.

We also use the Charles and Guryan (2008) survey-based estimates of the degree of racial prejudice of the marginal firm. As shown, states with above the median levels of this marginal racial prejudice indicator have significantly lower blacks' relative wages. Nonetheless, the intermarriage racial bias index remains negatively and significantly 
associated with blacks' relative wages even when controlling for the marginal racial prejudice indicator and the proportion of blacks in the workforce.

For the purposes of this paper, there are advantages to using the intermarriage racial bias index rather than survey-based measures of racial attitudes, though we draw consistent conclusions with either racial bias indicator. The intermarriage racial bias index is based on actual choices made prior to deregulation not survey responses made during the period of deregulation. Moreover, our empirical strategy requires that the measure of racial bias is invariant to bank deregulation and the resultant change in competition. If we differentiate states based on a measure of racial bias that itself reflects the effects of deregulation on the relative demand and supply of black workers, this will confound our strategy of identifying the causal impact of product market competition on the relative demand for black workers. The racial attitude surveys, however, are conducted during the period of bank deregulation. Furthermore, unlike Charles and Guryan (2008), we do not want to measure the racial preferences of the marginal employer. This will incorporate influences of both the relative demand for and supply of black workers. Rather, theory predicts that an intensification of competition will increase the relative demand for black workers and hence boost blacks' relative wages in states with a sufficiently high taste for discrimination, while holding the relative supply of black workers fixed. We test this.

In summary, we evaluate whether an exogenous lowering of entry barriers boosts the relative demand for black workers more in states with larger values of the racial bias indices. Measuring racial bias with error will bias the results against finding statistically significant results. We do not require that the racial bias measures are perfect; rather, we simply require that they provide information on racial prejudices across states.

\section{Results}

\subsection{Preliminaries}

Our empirical analysis rests on the assumption that the cross-state timing of bank deregulation was not affected by the racial wage gap. Figure 1 shows that neither the level of the estimated wage gap before deregulation (Panel A) nor its rate of change prior to deregulation (Panel C) explains cross-state differences in the timing of interstate bank deregulation. Panels B and D of Figure 1 confirm these findings for the case of intrastate deregulation. The size of the "bubbles" in the figures represent 
the size of the black workforce in each state, which corresponds to the weighting in the relative wage regressions below.

Our strategy also requires that bank deregulation increases the rate of new incorporations in the overall economy. In Table 2, we show that both interstate bank deregulation and intrastate branch deregulation exert a strong, positive impact on the log of new incorporations per capita over time. In columns $(1)-(3)$, we use simple dummy variables that equal zero before a state deregulates and one afterwards. Interstate deregulation enters significantly and positively, but intrastate does not, which is consistent with the findings in Black and Strahan (2002).

The results in Table 2 emphasize that the positive impact of deregulation on the rate of new incorporations grows over time. In columns (4) - (6), we include the number of years since deregulation and its quadratic. Interstate and Intrastate equal the number of years since interstate and intrastate bank deregulation respectively, and equal zero before deregulation. Both linear terms enter positively and significantly, while the quadratic terms are negative, but the coefficients are an order of magnitude smaller. The impact of each form of deregulation on new firm entry grows over time, reaching a maximum about a decade after interstate deregulation, and over two decades after intrastate deregulation. Economically, the coefficients in columns (4) and (5) indicate that five years after either inter- or intrastate deregulation the rate of new incorporations is about 10 percent greater than before deregulation. Furthermore, simultaneously deregulating inter- and intrastate restrictions boosts the rate of new incorporations by 18 percent after five years as shown in column (6).

Figure 2 more fully illustrates the positive, dynamic impact of both interstate and intrastate deregulation on the rate of new incorporations in state $s$ in period $t\left(N_{s t}\right)$. In Figure 2, we trace out the year-by-year relationship between both interstate and intrastate deregulation and the logarithm of new incorporations. We do this for two samples of states, those with above the median level of the racial bias index and those with below median levels. Specifically, we report estimated coefficients from the following regression:

$$
N_{s t}=\alpha+\beta_{1} \text { Inter }_{-9}+\ldots+\beta_{18} \text { Inter }_{+9}+\gamma_{1} \text { Intra }_{-9}+\ldots+\gamma_{18} \text { Intra }_{+9}+\delta_{s}+\delta_{t}+\varepsilon_{s t},
$$

where Inter $_{-j}$ equals one for the $j^{\text {th }}$ year before interstate deregulation, and Inter $+k$ equals one for the $k^{\text {th }}$ year after interstate deregulation, while Intra $a_{-j}$ equals one for the $j^{t h}$ year before intrastate deregulation, and $I n t r a_{+k}$ equals one for the $k^{t h}$ year after intrastate deregulation. These dummy variables equal zero in other years. We present 
results starting nine years before each form of bank deregulation and trace out the yearby-year dynamics of the relationship between deregulation and the wage gap until nine years after each type of bank deregulation. The year of deregulation is omitted and the regressions include state $\left(\delta_{s}\right)$ and year $\left(\delta_{t}\right)$ fixed effects. After detrending the series, Figure 2 illustrates the level and trend of the logarithm of new incorporations following each type of bank deregulation relative to the level and trend before deregulation. Specifically, we compute the trend in the coefficients on the dummy variables on bank deregulation prior to deregulation. We then detrend the entire series of estimated coefficients based on the pre-deregulation trend. The resulting figure illustrates the level and trend of the logarithm of new incorporations after bank deregulation relative to the patterns before deregulation.

There are three critical observations from Figure 2. First, interstate and intrastate bank deregulation boost the rate of new incorporations. This is crucial since we use bank deregulation to identify an exogenous intensification of competition.

Second, the impact of bank deregulation on the rate of new incorporations is not immediate. The effect of bank deregulation on the rate of new incorporations is still growing after five years. If bank deregulation affects blacks' relative wages by increasing the rate of new incorporations, therefore, we should also find that the dynamic impact of deregulation on black's relative wages materializes over time.

Third, the positive impact of inter- and intrastate bank deregulation on the rate of new incorporations occurs in both states with above the median level of the racial bias index and in states with below the median level of the racial bias index, though the marginal impact of intrastate deregulation on the rate of new incorporations in low racial bias states is less pronounced than in high racial bias states. Though the impact of bank deregulation on new incorporations does not have to be identical in high and low racial bias states, our empirical strategy requires that deregulation boosts the rate of new incorporations in both high and low racial bias states because we propose to evaluate whether the marginal impact of an exogenous increase in competition is greater in high racial bias states.

\subsection{Bank Deregulation and Blacks' Relative Wages}

\subsubsection{Reduced Form Analyses of Bank Deregulation}

We next assess the reduced form impact of Interstate and Intrastate on the relative

wage rates of black workers $\left(\hat{R}_{i s t}\right)$. For each form of deregulation, we present three 
specifications. First, blacks' relative wages are regressed on bank deregulation using the full sample. Second, we add an interaction term of deregulation and the racial bias dummy for each state, which equals one if the value of the racial bias index is greater than or equal to the sample median and zero otherwise. As suggested by theory, the impact of competition-enhancing bank deregulation on blacks' relative wages should be greater in more racially biased states. Third, rather than include an interaction term, we split the sample by the median value of the racial bias index, which allows the coefficients on state and year fixed effects to differ across the two subsamples. Throughout the analyses, we include state and year fixed effects.

Table 3 shows that bank deregulation has a large, significant impact on the relative wage rates of black workers in states with sufficiently high values of the racial bias index. In the regressions including the interaction of deregulation with the racial bias dummy, the impact of deregulation on blacks' relative wages is increasing in the state's racial bias index. The results hold for both inter- and intrastate bank deregulation. When splitting the sample between high and low racial bias states, the results indicate that a drop in entry barriers triggers a bigger increase in the relative demand for black workers in more racially biased economies.

Furthermore, by splitting the sample between high and low racial bias states, we employ a quasi-triple difference specification. In particular, there might be concerns that even though bank deregulation differs in its timing across states, there might be a confounding factor that reduces racial discrimination and is coincident with the state-specific timing of bank deregulation. By showing that bank deregulation only increases blacks' relative wages in high racial bias states as predicted by theory, this reduces the possibility that an unobserved state-year effect is driving the results, and it is fully consistent with the view that intensified competition reduces the manifestation of racial prejudices in labor market outcomes.

The estimated reduction in the racial wage gap from bank deregulation is economically meaningful. Consider column (4) of Table 3, which provides the regression results for states with above the median value of the racial bias index. Among these states, deregulation boosts the wage rates of black workers by 6 percentage points more than their white counterparts after five years $(6=0.012 * 5 * 100)$. Since the average racial wage gap in these high-bias states was 21 percent in 1976, the results suggest that interstate deregulation eliminates almost one-third of the initial racial wage gap. The results are virtually identical when using Intrastate, as shown in column (8). 


\subsubsection{Dynamic Analysis of the Effect of Bank Deregulation}

We next illustrate the dynamic relation between bank deregulation and the relative wages of blacks. In Figure 3, we trace out the year-by-year relationship between deregulation and the racial wage gap by following structure as we used to examine the dynamic relation between deregulation and new incorporations (Cf. equation (6) and Figure 2). The year of deregulation is omitted and the regressions include state and year fixed effects.

In examining the dynamic impact of deregulation on the racial wage gap, we use two samples of states. In Panel A of Figure 3, the subsample includes states with above the median values of the racial bias index. Panel B reports the dynamic relation between the relative wage rates of black workers and bank deregulation for the subsample of states with below the median values. The dashed line reports the estimated coefficients on the interstate deregulation dummy variables, while the solid line provides the estimated coefficients on the intrastate deregulation dummy variables.

Three crucial messages emerge from Figure 3. First, the impact of both interstate and intrastate bank deregulation on blacks' relative wages is much greater in states where the racial bias index is above the median than in states with lower values of the racial bias index. For example, the impact of interstate bank deregulation on blacks' relative wages rises over time in states with high values of the racial bias index, while interstate bank deregulation has virtually no effect on relative wage rates in states with low values of the racial bias index. Second, there is no evidence that trends or innovations in the wage gap precede either interstate or intrastate bank deregulation. Rather, blacks' relative wages rise after bank deregulation for an extensive period in states with high values of the racial bias index. Third, the impact of deregulation on black's relative wages grows over time. This is consistent with the dynamics of the relationship between deregulation and the rate of new incorporation documented in Figure 2 and Table 2.

While demonstrating the powerful impact of bank deregulation on the racial wage gap, these results do not provide direct evidence on the underlying causal mechanisms. We now examine the relationship between the rate of new incorporations and blacks'

relative wages to assess whether, and under which conditions, an exogenous increase in the rate of new incorporations reduces the black-white wage gap. 


\subsection{New Firm Entry and Blacks' Relative Wages}

\subsubsection{Reduced Form Analyses of New Firms Entry}

In examining the relationship between competition and the racial wage gap, we begin with reduced form OLS regressions. In Table 4, the dependent variable is blacks'

relative wages $\left(\hat{R}_{i s t}\right)$. The key regressor is the log of new incorporations per capita. The estimation is conducted on the full sample, and we also split the sample into states with below and above the median level of the racial bias index. In Panel A, we use the benchmark measure of blacks' relative wages, which is computed while conditioning on the standard Mincerian characteristics, education and potential work experience. In Panel B, we use an alternative measure of blacks' relative wages that also conditions on occupation, as discussed above.

There is a strong, positive association between the rate of new incorporations and the relative wages of black workers in states with above the median values of the racial bias index (column 3). The OLS estimates indicate that ten percent increase in the rate of new incorporations is associated with a 1.4 percent increase in blacks' relative wages in high racial bias states. In contrast, there is no relationship between the wage gap and our proxy for competition in states with low values of the racial bias index (column 2). These results hold both when using the benchmark, Mincerian measure of blacks' relative wages (Panel A) and also when conditioning on occupation (Panel B).

\subsubsection{SLS Analyses of New Firm Entry}

The final six columns of Panel A and Panel B of Table 4 report 2SLS estimates, where two different sets of instrumental variables are used to identify changes in the rate of new incorporations. First, the "linear" instruments simply include Interstate and Intrastate. Second, the "Non-Parametric" instruments included dummy variables for each year before and after both interstate and intrastate deregulation. These instruments are drawn from the analyses reported above in Table 2 and Figure 3. Furthermore, in reported robustness tests, we find that using Interstate and Intrastate plus their quadratic terms as instruments produces similar results.

As shown, the instrumental variables pass the validity tests. They significantly explain new incorporations as shown by the F-test of the excluded instruments. Furthermore, the instruments pass the test of the over-identifying restrictions (OIR test), meaning that the hypothesis that the instruments only affect blacks' relative wages through their effect on new incorporations is not rejected. In unreported robustness 
tests, we also show that the results are not driven by states in which deregulation failed to induce an increase in new firm entry which would run counter to theory and our identification strategy. Thus, we run the first-stage regression while omitting each state one-at-a-time. We then find which states are "flattening" the estimated relationship between new firm entry and deregulation in the first stage. When we eliminate these states, the results strengthen. This robustness test suggests that the effects of deregulation on racial discrimination are driven by states in which the "treatment" is affecting new firm entry, not through some spurious channel.

The exogenous increase in the rate of new incorporations dramatically boosted the wage rates of black workers relative to their white counterparts in states with above the median values of the racial bias index. As reported in columns (6) and (9) of both Panels A and B, an acceleration of the rate of new incorporations increased blacks' relative wages in high racial bias states. In contrast, the results in columns (5) and (8) indicate that a faster rate of new incorporations did not increase blacks' relative wages in states with below the median values of the racial bias index.

The economic impact the rate of new incorporations on blacks' relative wages is large in states with above the median level of the racial bias index. With either set of instrumental variables, the estimates indicate that a ten percent acceleration in the rate of new incorporations increases blacks' relative wages by about 2.5 percent in high racial bias states. The 2SLS parameter estimate is larger than the OLS estimate. This is consistent with the reverse causality argument made above. Specifically, if firms are attracted to states where blacks' relative wages are particularly low, OLS will underestimate the impact of a lowering of entry barriers on blacks' relative wages.Combining these results with those in Figure 2, the results suggest that bank deregulation boosted the rate of new incorporations by over $20 \%$ after five years in high racial bias states, which in turn increased blacks' relative wages by about five percent in these same states. These estimates indicate that by increasing competition, bank deregulation boosted blacks' relative wages by one-quarter of the initial racial wage gap in these states, which equaled, on average, 20 percent in the years before bank deregulation.

\subsubsection{New Firm Entry and Blacks' Relative Wages: Sensitivity Analyses}

The results are robust to using either the Charles and Guryan (2008) measure of racial prejudices $(C G)$ or the intermarriage racial bias index $(L L R)$ to categorize states as high- or low-racial bias states. Table 5 presents the OLS and 2SLS analyses of the relation between the racial wage gap and the rate of new incorporations. We use 
the linear instrument set and compute blacks' relative wages conditional on standard Mincerian traits and occupation. We use a common sample of states that is slightly smaller than in Table 4 because the $C G$ measure is unavailable for Hawaii, Idaho, Maine, Nebraska, Nevada, and New Mexico.

The strong positive impact of the rate of new incorporations on blacks' relative wages is robust to using the $C G$ racial prejudice indicator to classify states. In states with above the median values of the two racial bias indicators, the log of new incorporations per capita is positively associated with blacks' relative wages.

Figure 4 shows that the results are robust to considering the full range of possible combinations of (1) estimation strategy (OLS and 2SLS), (2) method for computing blacks' relative wages (either conditioning on standard Mincerian controls $(R)$ or also conditioning on occupation $(R o)$ ), (3) method for categorizing states by taste for discrimination ( $L L R$ or $C G$ ), and (4) using linear or non-parametric instrumental variables (Linear or Non-param.). Figure 4 plots each point estimate along with its $95 \%$ confidence interval. As shown, the results are robust. In terms of the instrumental variable results, there is only one specification in which the rate of new incorporation does not enter positively and significantly at the five percent level, and instead enters with a p-value of (0.10). This exception involves using the $C G$ indicator to define racial attitudes, and we have already discussed the advantages, in the context of our particular study, of using the intermarriage racial bias measure $(L L R)$.

\section{Robustness Checks}

In this section, we address concerns about several factors that could confound our ability to draw accurate inferences about the impact of bank deregulation that lowers entry barriers on racial wage discrimination. Some of these factors work against the reported findings, leading us to underestimate the beneficial effects of bank deregulation and the rate of new incorporations on blacks' relative wages. In these cases, we simply discuss our robustness tests without presenting tables. Other factors either play a central role in Becker's (1957) theory or potentially lead us to overestimate the impact of competition on racial discrimination. In these cases, we present correspondingly more information. 


\subsection{Racial Discrimination or the Poor}

Since bank deregulation exerts a disproportionately positive impact on the poor and blacks are on average comparatively poor (Beck, Levine, and Levkov, 2010), the current paper's analyses could reflect this income distributional effect, rather than the impact of bank deregulation and competition on blacks in particular.

Three observations, however, suggest that this is not the case. First, bank deregulation and the rate of new incorporations boosted blacks' relative wages in states with a high degree of racial bias. This is difficult to reconcile with the view that our results simply reflect a tightening of the distribution of income. Second, the results hold when computing relative wages conditional on occupation and industry. Thus, our findings indicate that even within low-paying (and high-paying) occupations and industries, blacks' relative wages rose with competition.

Third, and most directly, we perform a rank analysis and compare the change in blacks' relative wages with those of comparable whites across the full distribution of relative wage rates. If deregulation is simply helping the poor, we should not see that blacks converge toward whites at each point in the wage distribution.

The results show that bank deregulation, and the accompanying boost in the log of new incorporations per capita, disproportionately helped black workers across the full distribution of wages. Figure 5 shows the rank plot for the high racial bias states, and for the sample of states with below the median level of the racial bias index. The solid and dashed lines represent the location of blacks within the conditional log hourly wage distribution of whites before and after deregulation respectively. The median black

among the high racial bias states, for example, corresponds to the $28^{\text {th }}$ percentile white worker prior to deregulation and the $32^{\text {nd }}$ percentile white work after deregulation. The median black, therefore, gained four ranks in the white wage distribution as a result of deregulation, but only in high racial bias states. Consistent with the earlier results, there is little change in relative wage rates in the low racial bias states. These results suggest that deregulation exerted a particularly pronounced effect on black workers.

\subsection{Blacks' Relative Wages Within Industries}

Bank deregulation and its impact on the rate of new incorporations might induce a shift of black workers to better paying industries, rather than an increase in blacks' relative wages within industries. To assess whether the shift of black workers to higher-paying industries accounts for the increase in blacks' relative wages, we evaluate the impact of 
an increase in the rate of new incorporations on blacks' relative wages, where we not only compute blacks' relative wages by conditioning on education, potential experience, and occupation, but also by conditioning on industry. Thus, we compare the wages of black workers with the same observable traits as their white counterparts who are working in the same industry and the same occupation.

The results in Table 6 suggest that the intensification of competition boosted blacks' wages relative to comparable white workers within the same industry and occupation. Increased racial integration in the workplace does not fully account for the increase in blacks' relative wages following the boost in the rate of new incorporations. Both results - the increase in blacks' relative wages and the increase in racial integration in the workplace - are consistent with the taste-based view of racial discrimination.

\subsection{Relative Hours Worked}

We were concerned that blacks' relative wages could also rise if deregulation induced the labor supply curve of black males to shift leftward. If this occurs, the working hours of blacks could actually fall after deregulation relative to those of whites.

Table 7 reports the effects of bank deregulation and the log of new incorporations per capita on the relative working hours of blacks in high racial bias states using two approaches. We examine high racial bias states because this is where the rate of new incorporations increased blacks' relative wages. In the first approach, we trace the impact of bank deregulation, through the rate of new incorporations, to blacks' relative wages. We then examine the impact of these projected relative wages on blacks' relative annual hours worked. If an outward shift in the demand curve is causing the increase in blacks' relative wages, then we expect to find a positive coefficient on blacks' relative wages in the relative working hours regression.

In the second approach, we examine the impact of the log of new incorporations per capita on the relative working hours of blacks without tracing the effect through relative wages. Specifically, we reproduce the 2SLS analyses in Table 4 except that the dependent variable is the difference between the actual number of hours worked of each black worker and the projected annual hours worked of a white worker with identical traits. The difference between the actual and projected hours worked reflects the racial gap in hours. We use bank deregulation to identify an exogenous increase in new incorporations and assess the impact on this gap in working hours.

To compute relative working hours, we first estimate a labor supply equation every year on a sample of white males, while conditioning on state fixed effects and the same 
Mincerian characteristics used in the wage equation. Then, we use the resulting coefficient estimates to calculate the predicted number of hours worked of a white worker with each black worker's characteristics. Finally, we compute the relative working hours of each black worker as the difference between his actual and predicted working hours.

Since there is a meaningful kink in the labor supply curve between working and not working, we use both OLS and Tobit specifications and also examine the subsample of blacks with positive working hours. We use a standard bootstrapping procedure to correct the standard errors since the regressors are estimated.

We find that bank deregulation that increased the rate of new incorporations and boosted blacks' relative wages also increased the relative working hours of blacks. The evidence suggests that bank deregulation increased the relative demand for black workers. As shown, the impact is particularly pronounced among workers. This suggests that while deregulation increased the relative demand for black workers, bank deregulation did not significantly attract new black workers into the workforce. Most important given the focus of this paper, the Table 7 results clearly demonstrate that bank deregulation and competition did not shift black's labor supply curve to the left.

\subsection{Selection, Migration, and Self-Employment}

We were concerned that changes in the skill composition of black males in the economy could affect our evaluation of blacks' relative wages. Consequently, we calculate the projected wage rates for all working age (non-institutionalized) blacks in each state, whether they are working or not. We do this using the estimated returns to observable traits from equation (4) and using the actual traits of each black male. In this way, we compute the value of observable traits of all black males. Then, we evaluate the impact of bank deregulation on the composition of skills in the workforce.

Table 8 provides regression results of the projected wage rates of all relevant black males on a dummy variable if the person works, Inter state, and the interaction between Interstate and the dummy variable for working or not, as well as state and year fixed effects. There are similar regressions for Intrastate. The summation of the coefficients on Interstate and the interaction term provide information on whether the average value of the traits of workers changes after deregulation. The coefficient on Inter state provides information on the change in the average value of the traits of individuals who are not working following deregulation.

Deregulation did not have a significant effect on the average value of the traits of 
black workers. There is no evidence that bank deregulation substantively affected the skill composition of black workers. To the extent that observable traits are correlated with unobservable characteristics, these results further imply that the composition of unobservable traits did not change much following bank deregulation.

Deregulation could also affect migration across states. To assess this, we estimate the effect of deregulation on the fraction of black males within states. We find that the share of black males within states increased slightly after deregulation. This is consistent with a situation in which deregulation boosted the rate of new incorporations, reduced the racial wage gap, and attracted blacks from other states. Yet, as shown in Table 8, the net compositional changes of blacks in the economy due to deregulation did not have much of an effect on the skill composition of working blacks. There is no indication that migration leads us to overstate the beneficial effects of deregulation.

Similarly, the boost in blacks' relative wages could attract black males with comparatively low unobserved skills into the labor force, leading us to underestimate the degree to which the rate of new incorporations reduces racial wage differentials. A quantile regression at the median helps in assessing the importance of this potential bias by putting less weight on entrants of black workers with low unobserved skills.

We find no evidence that selection based on unobservables is causing us to underestimate the true effect of the rate of new incorporations. While the log of new incorporations per capita increases the relative demand for black workers, the number of new black males pulled into the labor force is relatively small, such that the median regression yields virtually identical results to the OLS coefficient estimates.

\subsection{Swimming Upstream}

Biases could arise from changes in the "prices" of unobserved skills. Although national trends in returns to unobserved skills will not affect our results because we control for year fixed effects, the intensification of competition when a state deregulates could increase returns to unobservable traits. If the average white worker has more of these unobserved traits than the average black worker, the average wage rate of whites will rise relative to that of blacks. This effect will cause the estimated value of blacks' relative wages to fall, even though racial discrimination is not rising.

Under these conditions, we will underestimate the true, positive effect of deregulation on the relative wages of blacks. This is sometimes called "swimming upstream" (Juhn Murphy and Pierce, 1991; Blau and Kahn, 1997; Blau and Kahn, 2000; and Mulligan and Rubinstein, 2008). To assess the importance of swimming upstream, we 
follow the literature and use quantile regressions. The goal is to compare black and white workers that are more similar in unobserved skills than when using OLS, which compares averages from both groups.

In unreported regressions, we confirm the existence of swimming upstream, suggesting that we are underestimating the beneficial effects of bank deregulation on blacks' relative wages when using OLS. The median regressions produce similar coefficient estimates to those from OLS. Moreover, in moving from lower quantiles to higher quantiles, we find that deregulation reduced a larger proportion of the racial wage gap. Under the assumption that the average white has more unobserved skills than the average black, these findings are consistent with the view that the racial wage gap closed more among white and black workers with comparable unobserved skills.

\section{Conclusions}

In this paper, we examined the relationship between bank deregulation and racial inequality in America. As Becker (1957) argued, taste-based discrimination by employers can produce an equilibrium gap between the wages of identical black and white workers. He further stressed that lowering barriers to the entry of new firms could erode the racial wage gap by reducing the impact of racial prejudices on the relative demand for black workers. A central implication of the taste-based discrimination theory is that lowering entry barriers will reduce the black-white wage differential only in economies where employers have a sufficiently strong "taste for discrimination."

We find that bank deregulation across the U.S. states boosted blacks' relative wages by lowering barriers to the entry of new firms but only in states with a high degree of racial bias. In reduced form specifications, bank deregulation that lowered entry barriers facing nonfinancial firms reduced the racial wage gap. In 2SLS, we use bank deregulation to identify an exogenous lowering of entry barriers. We find that the resultant increase in new incorporations eliminated more than one-fifth of the preexisting black-white wage differential in high racial bias states over a five-year period.

The paper emphasizes the powerful role of finance in shaping the economic opportunities of an historically oppressed group in the United States. Banking sector policies that facilitated competition materially enhanced blacks' relative wages. Our research shows that these improvements materialized through indirect channels: bank deregulation enhanced the functioning of labor markets throughout the economy, reducing racial inequality and boosting the economic opportunities of African Americans. 


\section{References}

[1] Altonji, Joseph G., and Rebecca M. Blank. 1999. "Race and Gender in the Labor Market. In Handbook of Labor Economics, vol. 3., edited by Orley Ashenfelter and David Card. St. Louis, MO: Elsevier: 3143-3259.

[2] Altonji, Joseph G., and Charles R. Pierret. 2001. "Employer Learning And Statistical Discrimination." Quarterly Journal of Economics 116 (February): 313-350.

[3] Amel, Dean F. 2008. "State Laws Affecting the Geographic Expansion of Commercial Banks." Unpublished manuscript. Washington, D.C.: Board of Governors of the Federal Reserve System.

[4] Arrow, Kenneth J. 1972. "Some Mathematical Models of Race Discrimination in the Labor Market." In Racial Discrimination in Economic Life, edited by A. H. Pascal. Lexington, MA: D.C. Heath Press, 187-204.

[5] Ashenfelter, Orley C., and Timothy Hannan. 1986. "Sex Discrimination and Product Market Competition: The Case of the Banking Industry." Quarterly Journal of Economics 101 (February): 149-174.

[6] Austen-Smith, David and Roland G. Fryer, Jr. 2005. "An Economic Analysis of 'Acting' White." Quarterly Journal of Economics 120 (May): 551-583.

[7] Autor, David H., Lawrence F. Katz, and Melissa S. Kearney. 2008. "Trends in U.S. Wage Inequality: Re-Assessing the Revisionists." Review of Economics and Statistics 90 (May): 300-325.

[8] Beck, Thorsten, Ross Levine, and Alexey Levkov. 2010. "Big Bad Banks? The Winners and Losers from Bank Deregulation in the United States." Journal of Finance 65, 1637-1667.

[9] Becker, Gary S. 1957. The Economics of Discrimination. The University of Chicago Press, Chicago.

[10] Bertrand, Marianne, and Sendhil Mullainathan. 2004. "Are Emily and Greg More Employable than Lakisha and Jamal? A Field Experiment on Labor Market Discrimination." American Economic Review 94 (September): 991-1013. 
[11] Black, Sandra E., and Philip E. Strahan. 2001. "The Division of Spoils: RentSharing and Discrimination in a Regulated Industry." American Economic Review 91 (September): 814-31.

[12] Black, Sandra E., and Philip E. Strahan. 2002. "Entrepreneurship and Bank Credit Availability." Journal of Finance 57 (December): 2807-32.

[13] Black, Sandra E., and Elizabeth Brainerd. 2004. "Importing Equality? The Effects of Globalization on Gender Discrimination." Industrial and Labor Relations Review 57 (July): 540-559.

[14] Blau, Francine D., and Lawrence M. Kahn. 1997. "Swimming Upstream: Trends in the Gender Wage Differential in the 1980s." Journal of Labor Economics 15 (January): 1-42.

[15] Blau, Francine D., and Lawrence M. Kahn. 2000. "Gender Differences in Pay." Journal of Economic Perspectives, 14: 75-99.

[16] Blau, Peter M. 1977. Inequality and Heterogeneity. New York: Free Press.

[17] Card, David, and Alan Krueger. 1992. "School Quality and Black-White Relative Earnings: A Direct Assessment." Quarterly Journal of Economics 107 (February): $151-200$.

[18] Carneiro, Pedro, James J. Heckman, and Dimitry V. Masterov. 2005. "Labor Market Discrimination and Racial Differences in Premarket Factors." Journal of Law and Economics 48 (April): 1-39.

[19] Cetorelli, Nicola, and Philip E. Strahan. 2006. "Finance as a Barrier to Entry: Bank Competition and Industry Structure in Local U.S. Markets." Journal of Finance 61 (February): 437-461.

[20] Charles, Kerwin K., and Jonathan Guryan. 2008. "Prejudice and the Economics of Discrimination." Journal of Political Economy 116, 773-809.

[21] Coate, Stephen, and Glenn C. Loury. 1993. "Will Affirmative-Action Policies Eliminate Negative Stereotypes?" American Economic Review 83 (December): 12201240 . 
[22] Donohue, John, and James J. Heckman. 1991. "Continuous versus Episodic Change: The Impact of Civil Rights Policy on the Economic Status of Blacks." Journal of Economic Literature 29 (December): 1603-43.

[23] Fryer, Roland G. Jr. 2011. "Racial Inequality in the 21st Century: The Declining Significance of Discrimination." Handbook of Labor Economics, Volume 4. Eds: Orley Ashenfelter and David Card. North-Holland, Elsevier Press.

[24] Fryer, Roland G. Jr., Steven D. Levitt. 2004. "Understanding the Black-White Test Score Gap in the First Two Years of School." Review of Economics and Statistics 86 (May), 447-464.

[25] Heckman, James J., Jora Stixrud, and Sergio Urzua. 2006. "The Effects of Cognitive and Noncognitive Abilities on Labor Market Outcomes and Social Behavior." Journal of Labor Economics 24 (July): 411-482.

[26] Heywood, John S., and James H. Peoples. 1994. "Deregulation and the Prevalence of Black Truck Drivers." Journal of Law and Economics 37 (April): 135-155.

[27] Hubbard, Glenn R., and Darius Palia. 1995. "Executive Pay and Performance: Evidence from the U.S. Banking Industry." Journal of Financial Economics 39 (September): 105-30.

[28] Jayaratne, Jith, and Philip E. Strahan. 1996. "The Finance-Growth Nexus: Evidence from Bank Branch Deregulation." Quarterly Journal of Economics 111 (August ): 639-670.

[29] Jayaratne, Jith, and Philip E. Strahan. 1998. "Entry Restrictions, Industry Evolution, and Dynamic Efficiency: Evidence from Commercial Banking." Journal of Law and Economics 41 (April): 239-73.

[30] Jencks, Christopher. 1998. "Racial Bias in Testing." In The Black-White Test Score Gap, Eds: Christopher Jencks and Meredith Phillips, The Brookings Institution Press, 55-85.

[31] Juhn, Chinhui, Kevin M. Murphy, and Brooks Pierce. 1991. "Accounting for the Slowdown in Black-White Wage Convergence." In Workers and Their Wages: Changing patterns in the United States, edited by Marvin Kosters, Washington, DC: American Enterprise Press: 107-143. 
[32] Juhn, Chinhui, Kevin M. Murphy, and Brooks Pierce. 1993. "Wage Inequality and the Rise in Returns to Skill." Journal of Political Economy 101 (June): 410-442.

[33] Katz, Lawrence F., and David H. Autor. 1999. "Changes in the Wage Structure and Earnings Inequality." In Handbook of Labor Economics, edited by Orley Ashenfelter and David Card, Amsterdam: North-Holland Elsevier Publishers.

[34] Kerr, William, and Ramana Nanda. 2009. "Democratizing Entry: Banking Deregulations, Financing Constraints, and Entrepreneurship." Journal of Financial Economics, 94 (October): 124-149.

[35] Kroszner, Randall, and Philip E. Strahan. 1999. "What Drives Deregulation? Economics and Politics of the Relaxation of Bank Branching Deregulation." Quarterly Journal of Economics 114 (November): 1437-67.

[36] Lang, Kevin, Michael Manove, and William Dickens. 2005. "Racial Discrimination in Markets with Announced Wages." American Economic Review 95: 1327-40.

[37] Levine, Ross. 2005. "Finance and Growth: Theory and Evidence." In Handbook of Economic Growth, edited by Philippe Aghion and Steven Durlauf, Amsterdam: North-Holland Elsevier Publishers.

[38] Massey, Douglas S. and Nancy A. Denton. 1987. "Trends in the Residential Segregation of Blacks, Hispanics and Asians: 1970-1980." American Sociological Review 52 (December): 802-825.

[39] Mulligan, Casey B., and Yona Rubinstein. 2008. "Selection, Investment, and Women's Relative Wages Over Time." Quarterly Journal of Economics 123 (August): 1061-1110.

[40] Murnane, Richard J., John B. Willett, Kristen L. Bub, and Kathleen McCartney. 2006. "Understanding Trends in the Black-White Achievement Gaps During the First Years of School." Brookings-Wharton Papers on Urban Affairs: 2006, 97-135.

[41] Neal, Derek A. 2007. "Why has Black-White Skill Convergence Stopped?" Handbook of the Economics of Education, Volume 1. Eds: Eric A. Hanushek and Finis Welch, Chapter 9, Elsevier Press.

[42] Neal, Derek A., and William R. Johnson. 1996. "The Role of Premarket Factors in Black-White Wage Differences." Journal of Political Economy 104 (October): 869-895. 
[43] Oster, Sharon M. 1975. "Industry Differences in the Level of Discrimination Against Women," Quarterly Journal of Economics 89 (May): 215-229.

[44] Peoples, James H., and Wayne K. Talley. 2001. "Black-White Earnings Differential: Privatization versus Deregulation." American Economic Review Papers and Proceedings 91 (May): 164-168.

[45] Phelps, Edmund S. 1972. "The Statistical Theory of Racism and Sexism," American Economic Review 62 (September): 659-661.

[46] Qian, Zhenchao. 1997. "Breaking the Racial Barriers: Variations in Interracial Marriage Between 1980 and 1990," Demography 34 (May): 263-276.

[47] Rubinstein Yona, and Dror Brenner. 2009. "Pride and Prejudice: Evidence from the 'Promised Land'". Brown University mimeo.

[48] Shepherd, William G., and Sharon G. Levin. 1973. "Managerial Discrimination in Large Firms." The Review of Economics and Statistics 55 (November): 412-422.

[49] Welch, Finis R. 1975. "Human Capital Theory: Education, Discrimination, and Life Cycles." American Economic Review 65 (May): 63-73.

[50] White, Eugene N. 1982. "The Political Economy of Banking Regulation, 18641933." Journal of Economic History 42 (March): 33-40. 
Figure 1

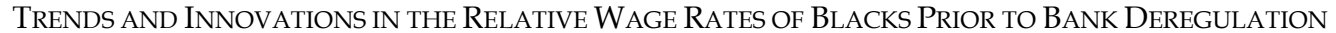

A.

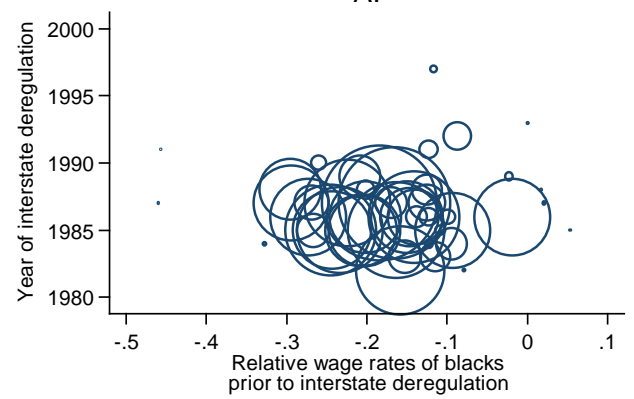

C.

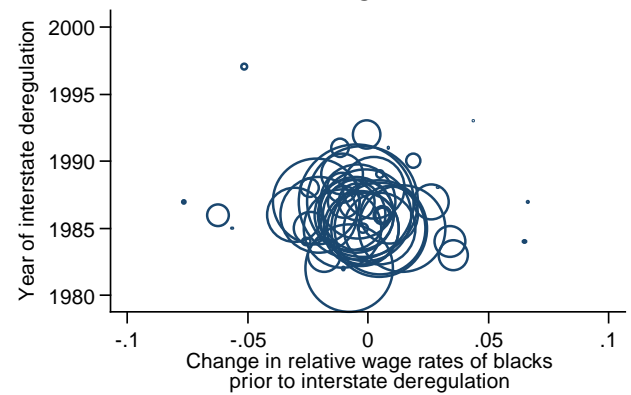

B.

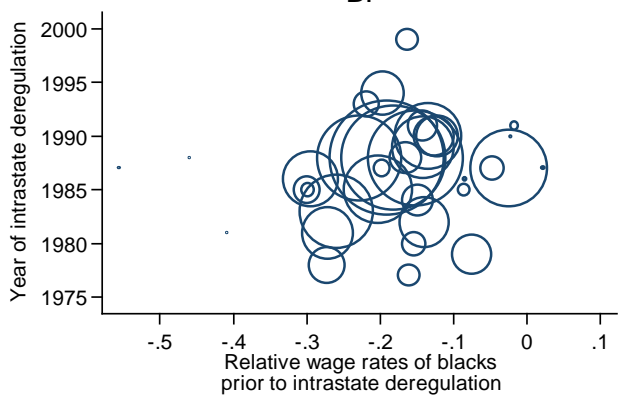

D.

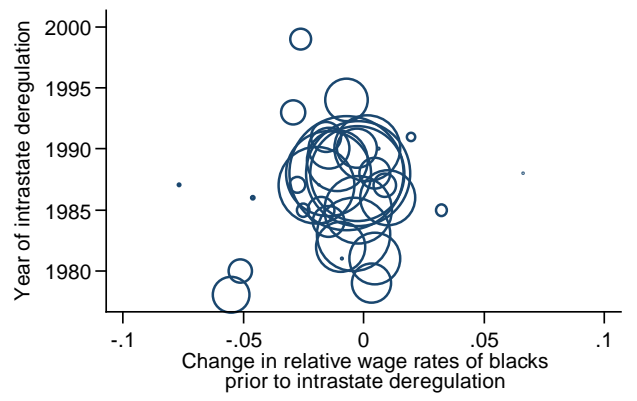

NotE - Figures A and B plot the year of bank deregulation against the average black-white wage differential prior to deregulation. In Figure A we consider years prior to interstate deregulation. In Figure $B$ we consider years prior to intrastate deregulation. Figures $C$ and D plot the year of bank deregulation against the change in the black-white wage differential prior to deregulation. In Figure $\mathrm{C}$ we consider years prior to interstate deregulation. In Figure D we consider years prior to intrastate deregulation. All statistics are weighted by the number of black workers. 
Figure 2

THE IMPACT OF DEREGULATION ON ENTRY OF FIRMS

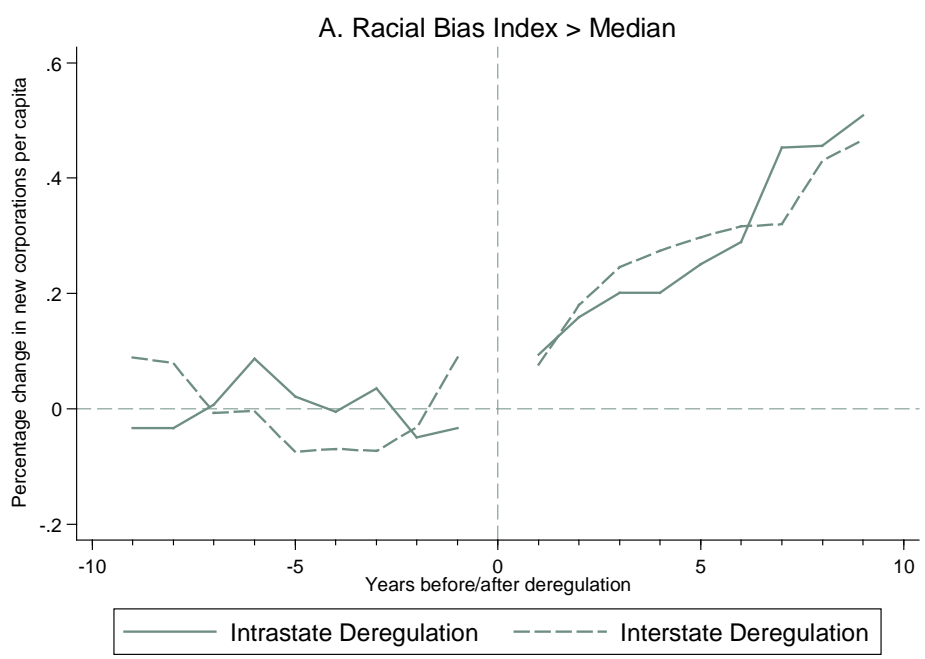

B. Racial Bias Index < Median

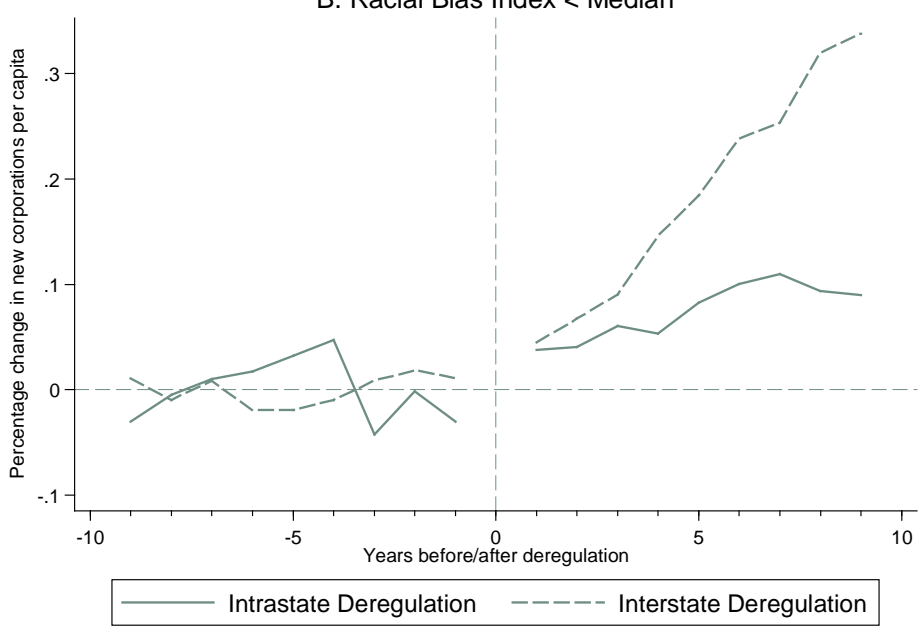

SOURCES - Data on new corporations per capita are taken from Black and Strahan (2002). Dates of intrastate and interstate deregulations are taken from Kroszner and Strahan (1999).

NOTE - The figures plot the impact of interstate and intrastate bank deregulations on log new corporations per capita. The upper figure is for states with racial bias index above the median. The lower figure is for state with racial bias index below the median. We consider an 18 years window spanning from 9 years before deregulations until 9 years after deregulations. The solid lines represent the impact of intrastate deregulation on log new per capita. The dashed lines represent the impact of interstate deregulation on log new corporations per capita. Specifically, we report estimated coefficients from the following regression:

$$
Y_{\text {st }}=\alpha+\beta_{1} \text { Intra }_{-9}+\gamma_{1} \text { Inter }_{-9}+\beta_{2} \text { Intra }_{-8}+\gamma_{2} \text { Inter }_{-8}+\ldots+\beta_{18} \text { Intra }_{+9}+\gamma_{18} \text { Inter }_{+9}+\delta_{\mathrm{s}}+\delta_{\mathrm{t}}+\varepsilon_{\mathrm{st}}
$$

$Y_{\text {st }}$ is $\log$ new corporations per capita in state $s$ and year $t$. Intra ${ }_{-j}$ equals one for states in the $j^{\text {th }}$ year before intrastate deregulation and equals zero otherwise. Intra $+\mathrm{k}$ equals one for states in the $\mathrm{k}^{\text {th }}$ year after intrastate deregulation and equals zero otherwise. Similarly, Inter ${ }_{-j}$ equals one in states in the $j^{\text {th }}$ year before interstate deregulation and equals zero otherwise. Inter $+k$ equals one in states in the $\mathrm{k}^{\text {th }}$ year after interstate deregulation and equals zero otherwise. $\delta_{\mathrm{s}}$ and $\delta_{\mathrm{t}}$ are state and year fixed effects, respectively. We exclude the year of intrastate and interstate deregulation, thus estimating the dynamic effect of deregulation on log new corporations per capita relative to the corresponding year of deregulation. We de-trend the coefficients by prior trends and normalize their average prior to deregulation to be zero. The estimates are weighted by the number of black workers. 
Figure 3

THE IMPACT OF DEREgUlation ON THE RELATIVE WAGE RATES OF BLACKS

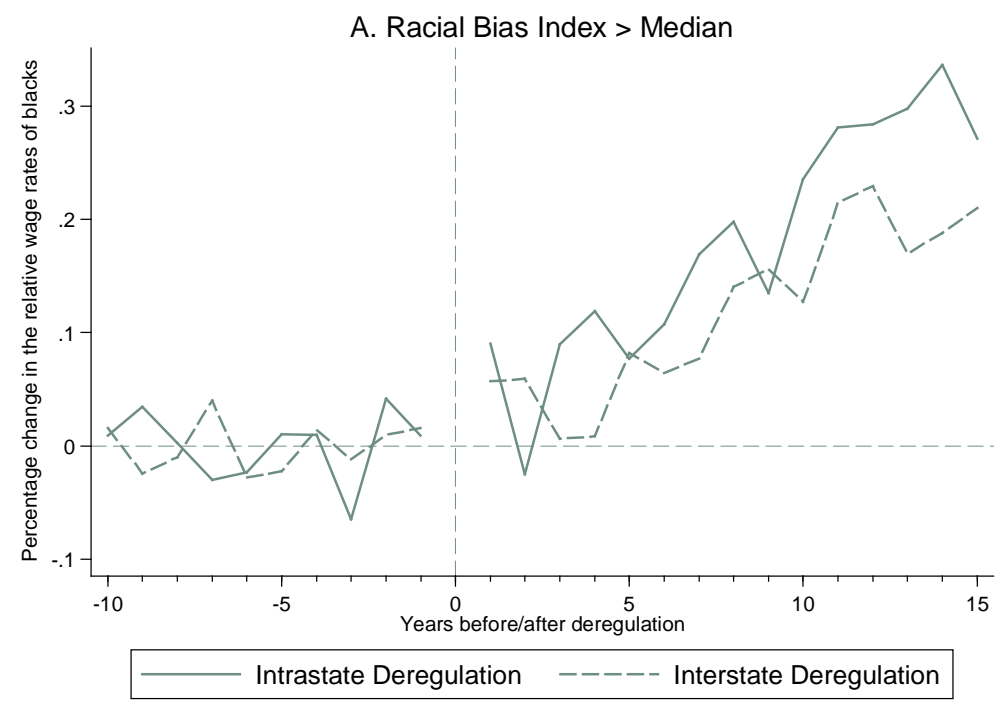

B. Racial Bias Index < Median

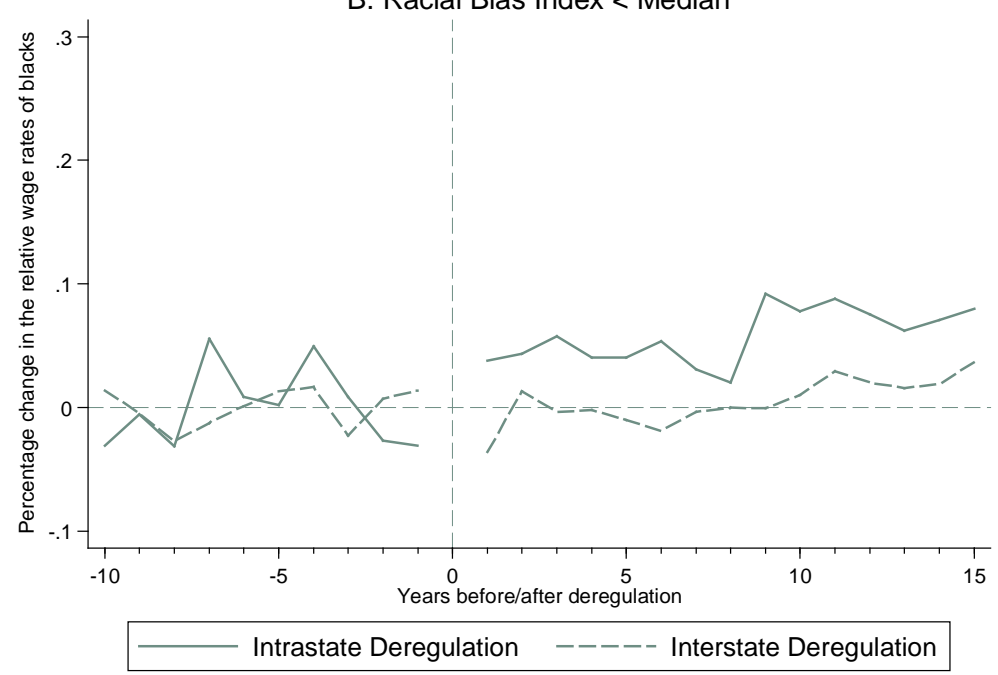

NOTE - The figures plot the impact of interstate and intrastate bank deregulations on the relative wage rates of blacks. The upper figure is for states with racial bias index above the median. The lower figure is for state with racial bias index below the median. We consider a 25 year window, spanning from 10 years before deregulation until 15 years after deregulation. The solid lines represent the impact of intrastate deregulation on the relative wage rates of blacks. The dashed lines represent the impact of interstate deregulation on the relative wage rates of blacks. Specifically, we report estimated coefficients from the following regression:

$$
\hat{R}_{i s t}^{B}=\alpha+\beta_{1} D_{s t}^{-10}+\beta_{2} D_{s t}^{-9}+\ldots+\beta_{25} D_{s t}^{+15}+\delta_{s}+\delta_{t}+v_{\text {ist }}
$$

The $D^{\prime}$ s equal zero, except as follows: $D_{-j}$ equals one for states in the $j^{\text {th }}$ year before deregulation, while $D_{+j}$ equals one for states in the $j^{\text {th }}$ year after deregulation. We exclude the year of deregulation, thus estimating the dynamic effect of deregulation on the relative wage rates of blacks relative to the year of deregulation. We de-trend the coefficients by prior trends and normalize their average prior to deregulation to be zero. The estimates are weighted by the number of black workers. 
Figure 4

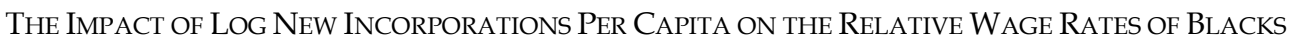

DIFFERENT OLS AND 2SLS SPECIFICATIONS

(DASHED LINES REPRESENT 95\% CONFIDENCE INTERVALS)

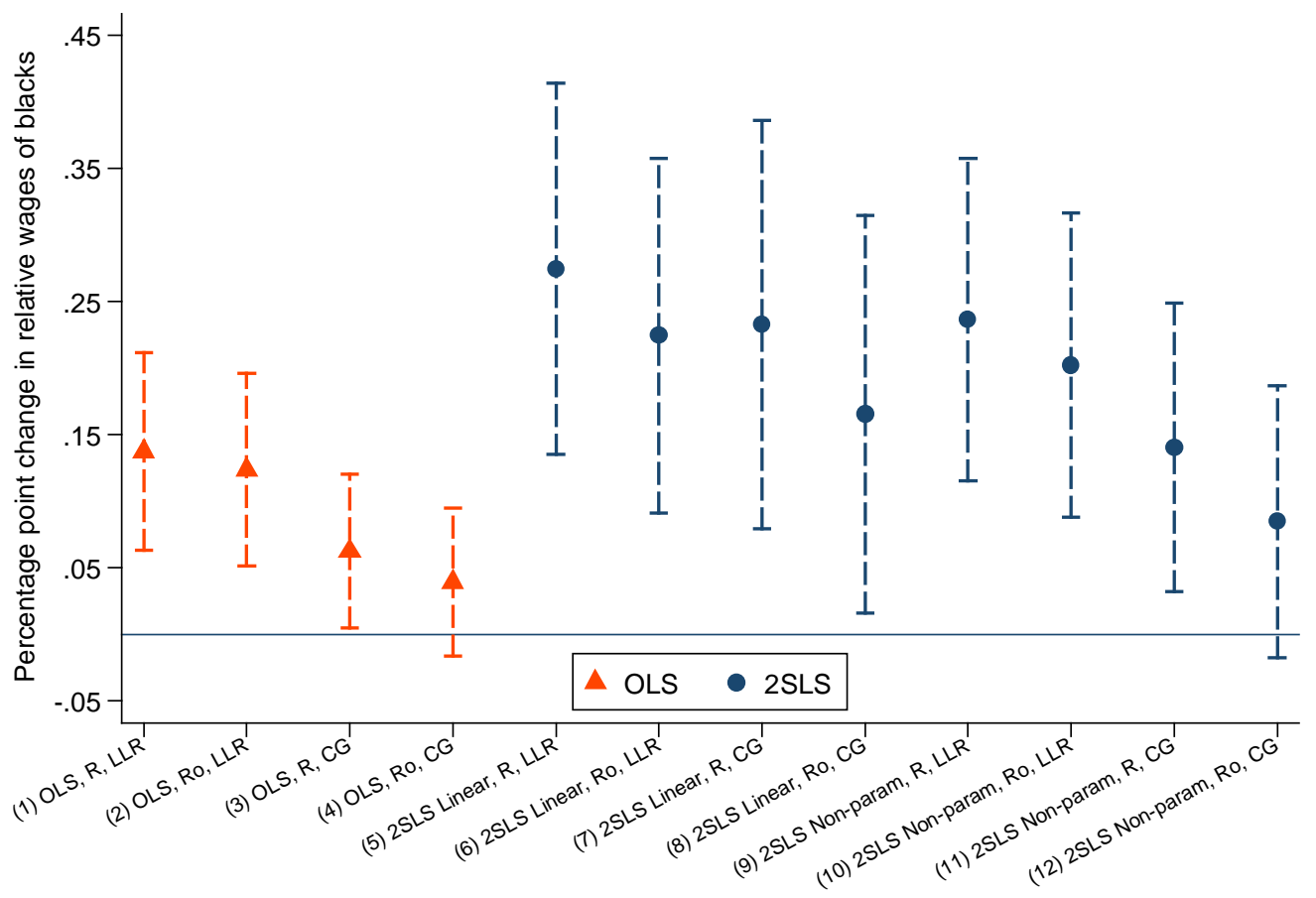

Specification

NOTE - The circles represent the estimated impact of log new incorporations per capita on the relative wages of blacks. The dashed lines represent the corresponding $95 \%$ confidence intervals, adjusted for state and year clustering. The estimated coefficients and the confidence intervals are from twelve different specifications. The notation in the specifications is as follows: OLS - Ordinary Least Squares; 2SLS Linear - Two-Stage Least Squares with Interstate and Intrastate entering linearly; 2SLS Non-param - Two-Stage Least Squares with Interstate and Intrastate entering non-parametrically; $\mathrm{R}$ - relative wages of blacks, where the relative wages are conditional on years of completed education and quartic in potential experience; Ro - relative wages of blacks, where the relative wages are conditional on years of completed education, a quartic in potential experience, and occupation fixed effects; LLR - states with racial bias index above the median; CG - states with marginal racial prejudice (From Charles and Guryan, 2008) above the median. The different specifications are: (1) OLS, with relative wages conditional on education and experience, in states below the median racial bias index, (2) OLS, with relative wages conditional on education, experience, and occupation, in states below the median racial bias index, (3) OLS, with relative wages conditional on education and experience, in states below the median marginal racial prejudice, (4) OLS, with relative wages conditional on education, experience, and occupation, in states below the median marginal racial prejudice, (5) 2SLS with linear instruments, relative wages conditional on education and experience, in states below the median racial bias index, (6) 2SLS with linear instruments, relative wages conditional on education, experience, and occupation, in states below the median racial bias index, (7) 2SLS with linear instruments, relative wages conditional on education and experience, in states below the median marginal racial prejudice, (8) 2SLS with linear instruments, relative wages conditional on education, experience, and occupation, in states below the median marginal racial prejudice, (9) 2SLS with non-parametric instruments, relative wages conditional on education and experience, in states below the median racial bias index, (10) 2SLS with non-parametric instruments, relative wages conditional on education, experience, and occupation, in states below the median racial bias index, (11) 2SLS with non-parametric instruments, relative wages conditional on education and experience, in states below the median marginal racial prejudice, (12) 2SLS with non-parametric instruments, relative wages conditional on education, experience, and occupation, in states below the median marginal racial prejudice. Measures of marginal racial prejudice are obtained from Charles and Guryan (2008). All estimates are weighted by sampling weights provided by the Current Population Survey. 
Figure 5

The Location of Blacks in the White Wage Distribution Before ANd After Deregulation
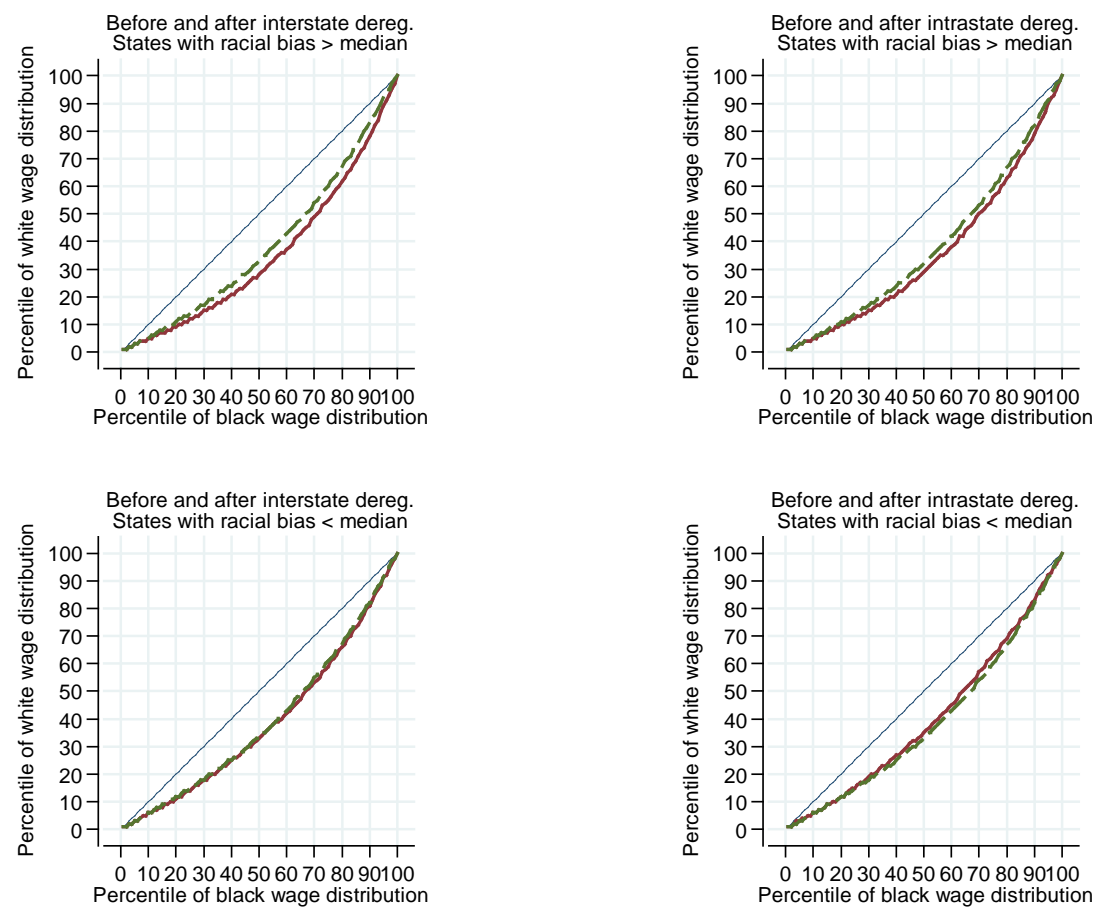

NOTE - The figures provide rank analyses and compare the change in black workers' relative wages with those of comparable whites across the full distribution of wage rates, before and after bank deregulation. The results in the plots were obtained using the following procedure: First, we calculate residuals for black and white workers from equation (7). We keep 100 black workers, each corresponding to a different percentile of black workers' relative log hourly wage distribution. Next, we calculate their position in the white workers' log hourly wage distribution. We repeat this procedure before (solid line) and after (dashed line) inter- and intrastate deregulations. The upper figures refer to states with racial bias index above the median. The lower figures refer to states with racial bias index below the median. We use sampling weights in all estimations. 
Table 1

The Racial Bias Index, Survey Measures of Racial Prejudice, And Relative Wages

\begin{tabular}{|c|c|c|c|}
\hline $\begin{array}{l}\text { Panel A: Correlation Coefficients Between the Different } \\
\text { Measures of Taste for Discrimination }\end{array}$ & $\begin{array}{c}\text { Fraction whites } \\
\text { who support law } \\
\text { against interracial } \\
\text { marriage } \\
\text { (1) }\end{array}$ & $\begin{array}{c}\text { Fraction } \\
\text { whites who } \\
\text { would not vote } \\
\text { for black } \\
\text { president } \\
(2) \\
\end{array}$ & $\begin{array}{c}\text { Fraction whites } \\
\text { who support } \\
\text { right to } \\
\text { segregate } \\
\text { neighborhoods } \\
\text { (3) }\end{array}$ \\
\hline \multirow[t]{2}{*}{ Racial bias index } & 0.36 & 0.35 & 0.31 \\
\hline & $\{0.02\}$ & $\{0.02\}$ & $\{0.04\}$ \\
\hline Observations & 43 & 43 & 43 \\
\hline
\end{tabular}

Panel B: Taste for Discrimination and Dependent Variable: Relative Wages of Blacks

\begin{tabular}{|c|c|c|c|c|}
\hline Relative Wages of Blacks & (1) & (2) & (3) & (4) \\
\hline \multirow[t]{2}{*}{ Racial bias index $>$ median } & $-.079 * * *$ & & $-.072 * * *$ & $-.065^{* * *}$ \\
\hline & $(.013)$ & & $(.014)$ & $(.012)$ \\
\hline \multirow[t]{2}{*}{ Marginal racial prejudice $>$ median } & & $-.058^{* * *}$ & $-.042^{* * *}$ & -.002 \\
\hline & & $(.015)$ & $(.015)$ & $(.017)$ \\
\hline \multirow[t]{2}{*}{ Share of blacks in $1970 \geq 10 \%$} & & & & $-.082^{* * *}$ \\
\hline & & & & $(.013)$ \\
\hline Observations & 10,076 & 10,076 & 10,076 & 10,076 \\
\hline
\end{tabular}

NOTE - Panel A reports correlation coefficients between (1) The racial bias index, which is based on interracial marriages in 1970, and (2) three recent survey-based indicators of racial prejudice from Charles and Guryan (2008). Panel B reports estimated coefficients from four regressions, where the dependent variable is blacks' relative wage rates. Relative wages are conditional on five indicators of years of completed education $(0-8,9-11,12,13-15$, and 16+) and a quartic in potential experience. Estimates are weighted by sampling weights provided by the Current Population Survey. In column (1), the regressor is an indicator which equals one if the racial bias index above the median and zero otherwise. In column (2) the regressor is an indicator which equals one if the marginal racial prejudice above the median and zero otherwise. The marginal racial prejudice index is the $p^{\text {th }}$ percentile of the distribution of an aggregate index of racial prejudice, where $p$ is the percentile of workforce that is black. The marginal racial prejudice index is taken from Charles and Guryan (2008). Column (3) includes simultaneously the regressors from columns (1) and (2). In column (4) we also control for an indicator which equals one if the proportion of blacks in the workforce in 1970 is above $10 \%$. The regressions include black workers prior to interstate and intrastate bank deregulation, so that the reported number of observations equals 10,076. All regressions include year fixed effects. We do not include state fixed effects because the regressors are fixed for each state and do not change over time. Standard errors are clustered at the state-year level and appear in parentheses; pvalues are in brackets. ${ }^{*}, * *$, and ${ }^{* * *}$ indicate significance at the $10 \%, 5 \%$, and $1 \%$ respectively. 
Table 2

BANK Deregulation ANd Log NeW InCORPorations Per CAPITA

\begin{tabular}{|c|c|c|c|c|c|c|}
\hline & (1) & $(2)$ & (3) & $(4)$ & (5) & (6) \\
\hline \multirow[t]{2}{*}{ Interstate dummy } & $.084^{* * *}$ & & $.082^{* *}$ & & & \\
\hline & $(.031)$ & & $(.031)$ & & & \\
\hline \multirow[t]{2}{*}{ Intrastate dummy } & & .040 & .038 & & & \\
\hline & & $(.041)$ & $(.041)$ & & & \\
\hline \multirow[t]{2}{*}{ Interstate } & & & & $.032 * *$ & & $.029 * *$ \\
\hline & & & & $(.015)$ & & $(.014)$ \\
\hline \multirow[t]{2}{*}{ Interstate squared } & & & & -.002 & & -.002 \\
\hline & & & & $(.001)$ & & $(.001)$ \\
\hline \multirow[t]{2}{*}{ Intrastate } & & & & & $.021^{* * *}$ & $.019 * *$ \\
\hline & & & & & $(.008)$ & $(.008)$ \\
\hline \multirow[t]{2}{*}{ Intrastate squared } & & & & & $-.0004^{*}$ & $-.0004^{*}$ \\
\hline & & & & & $(.0002)$ & $(.0002)$ \\
\hline Observations & 882 & 882 & 882 & 882 & 882 & 882 \\
\hline
\end{tabular}

NOTE - The table shows the impact of various measures of bank deregulation on log new incorporations per capita. Robust standard errors are adjusted for state-level clustering and appear in parentheses. Intrastate dummy equals one in the years after a state permits branching via mergers and acquisitions and zero otherwise. Interstate dummy equals one in the years after a state permits interstate banking and zero otherwise. Interstate is equal to years since interstate deregulation and is equal to zero before interstate deregulation. Intrastate is equal to years since intrastate deregulation and is equal to zero before intrastate deregulation. New incorporations are from Dun and Bradstreet. Dates of intrastate and interstate bank deregulations are from Kroszner and Strahan (1999) and Amel (2008). The sample is for the years 1977-1994 and excludes Delaware and South Dakota. All regressions include state and year fixed effects. There are no other covariates. ${ }^{*},{ }^{* *}$, and ${ }^{* * *}$ indicate significance at the $10 \%, 5 \%$, and $1 \%$, respectively. 
Table 3

BANK DeREgulation AND Relative Wage RATES

\begin{tabular}{|c|c|c|c|c|c|c|c|c|}
\hline & \multicolumn{4}{|c|}{ Interstate Deregulation } & \multicolumn{4}{|c|}{ Intrastate Deregulation } \\
\hline & & & \multicolumn{2}{|c|}{ Racial Bias Index: } & & & \multicolumn{2}{|c|}{ Racial Bias Index: } \\
\hline & \multirow{2}{*}{\multicolumn{2}{|c|}{$\begin{array}{c}\text { All } \\
\text { States }\end{array}$}} & \multirow{3}{*}{$\begin{array}{c}\text { Below } \\
\text { Median } \\
(3)\end{array}$} & \multirow{3}{*}{$\begin{array}{c}\begin{array}{c}\text { Above } \\
\text { Median }\end{array} \\
(4)\end{array}$} & \multirow{2}{*}{\multicolumn{2}{|c|}{$\begin{array}{c}\text { All } \\
\text { States }\end{array}$}} & \multirow{3}{*}{$\begin{array}{c}\begin{array}{c}\text { Below } \\
\text { Median }\end{array} \\
(7)\end{array}$} & \multirow{3}{*}{$\begin{array}{c}\begin{array}{c}\text { Above } \\
\text { Median }\end{array} \\
(8)\end{array}$} \\
\hline & & & & & & & & \\
\hline & $(1)$ & $(2)$ & & & $(5)$ & $(6)$ & & \\
\hline \multirow[t]{2}{*}{ Years since deregulation } & .001 & .004 & .003 & $.012^{*}$ & $.005^{* * *}$ & $.005^{* * *}$ & $.004^{* * *}$ & $.011^{\star * *}$ \\
\hline & $(.003)$ & $(.003)$ & $(.003)$ & $(.007)$ & $(.001)$ & $(.001)$ & $(.002)$ & $(.002)$ \\
\hline \multirow{2}{*}{$\begin{array}{l}\text { (Years since deregulation) } x \\
\quad(\text { Racial bias index }>\text { median) }\end{array}$} & & $.003^{* * *}$ & & & & $.004^{* * *}$ & & \\
\hline & & $(.001)$ & & & & $(.001)$ & & \\
\hline \multirow[t]{2}{*}{ Impact after five years } & .006 & $.037^{* *}$ & .013 & $.061^{*}$ & $.023^{* * *}$ & $.044^{* * *}$ & $.022^{* * *}$ & $.057^{* * *}$ \\
\hline & $(.015)$ & $(.016)$ & $(.016)$ & $(.034)$ & $(.006)$ & $(.007)$ & $(.007)$ & $(.012)$ \\
\hline \multicolumn{9}{|l|}{ Impact after five years } \\
\hline as a share of sample's initial wage gap & $3 \%$ & $21 \%$ & $9 \%$ & $29 \%$ & $13 \%$ & $25 \%$ & $15 \%$ & $27 \%$ \\
\hline Observations & 73,801 & 73,801 & 48,367 & 25,434 & 73,801 & 73,801 & 48,367 & 25,434 \\
\hline
\end{tabular}

NOTE - The dependent variable is the relative wage rates of blacks. Relative wages are conditional on five indicators of years of completed education (0-8, 9-11, 12, 13-15, and 16+) and a quartic in potential experience. Estimates are weighted by sampling weights provided by the Current Population Survey. Standard errors are adjusted for state-year clustering and appear in parentheses. All regressions include state and year fixed effects. The reported number of observations is for blacks only. Details about sample construction are in Appendix Table 2. In columns (1)-(4), "years since deregulation" stands for years since interstate deregulation; in columns (5)-(8), "years since deregulation" stands for years since intrastate deregulation. In columns (2) and (6), years since deregulation is interacted with an indicator which equals one if the racial bias index is above the median and zero otherwise. In columns (1), (2), (5), and (6) we include the entire sample. In columns (3) and (7) we include only states with racial bias index below the median. In columns (4) and (8) we include only states with racial bias index above the median. The racial bias index is based on rate of interracial marriages using the 1970 Census of Population. Appendix Table 3 lists the racial bias index for each state. The average initial racial wage gap is $17 \%$ for all states, $15 \%$ for states with a racial bias index below the median, and $21 \%$ for states with a racial bias index above the median. *, **, and *** indicate significance at the $10 \%, 5 \%$, and $1 \%$ respectively. 


\section{Table 4}

THE IMPACT OF LOG NEW INCORPORATIONS PER CAPITA ON RELATIVE WAGE RATES: OLS AND 2SLS EsTIMATES

\begin{tabular}{|c|c|c|c|c|c|c|c|c|c|}
\hline & \multicolumn{3}{|c|}{ OLS } & \multicolumn{3}{|c|}{ 2SLS: Linear } & \multicolumn{3}{|c|}{ 2SLS: Non-Parametric } \\
\hline & \multirow[b]{2}{*}{ All } & \multicolumn{2}{|c|}{ Racial Bias Index: } & \multirow{3}{*}{$\begin{array}{c}\text { All } \\
\text { States }\end{array}$} & \multicolumn{2}{|c|}{ Racial Bias Index: } & \multirow{3}{*}{$\begin{array}{c}\text { All } \\
\text { States }\end{array}$} & \multicolumn{2}{|c|}{ Racial Bias Index: } \\
\hline & & Below & Above & & Below & Above & & Below & Above \\
\hline & States & Median & Median & & Median & Median & & Median & Median \\
\hline & $(1)$ & $(2)$ & (3) & $(4)$ & $(5)$ & $(6)$ & $(7)$ & $(8)$ & $(9)$ \\
\hline \multicolumn{10}{|c|}{ Panel A: Relative Wage Rates are Conditional on Education and Potential Experience } \\
\hline \multirow[t]{2}{*}{ Log new incorporation per capita } & .018 & -.038 & $.137^{* * *}$ & .042 & -.080 & $.267^{* * *}$ & .019 & $-.122^{* *}$ & $.235^{* * *}$ \\
\hline & $(.022)$ & $(.023)$ & $(.038)$ & $(.064)$ & $(.071)$ & $(.071)$ & $(.048)$ & $(.054)$ & $(.062)$ \\
\hline F-test of excluded instruments & & & & 21.8 & 8.2 & 26.8 & 3.0 & 2.3 & 113.5 \\
\hline OIR test (p-value) & & & & .003 & .174 & .134 & .608 & .518 & .086 \\
\hline Observations & 37,876 & 24,754 & 13,122 & 37,876 & 24,754 & 13,122 & 37,876 & 24,754 & 13,122 \\
\hline \multicolumn{10}{|c|}{ Panel B: Relative Wage Rates are Conditional on Education, Potential Experience, and Occupation } \\
\hline \multirow[t]{2}{*}{ Log new incorporation per capita } & .016 & -.029 & $.122^{* * *}$ & .023 & -.026 & $.214^{* * *}$ & .020 & -.079 & $.198^{* * *}$ \\
\hline & $(.020)$ & $(.023)$ & $(.037)$ & $(.064)$ & $(.071)$ & $(.068)$ & $(.046)$ & $(.053)$ & $(.058)$ \\
\hline F-test of excluded instruments & & & & 21.8 & 8.2 & 26.8 & 3.0 & 2.3 & 113.5 \\
\hline OIR test (p-value) & & & & .046 & .358 & .123 & .845 & .683 & .082 \\
\hline Observations & 37,876 & 24,754 & 13,122 & 37,876 & 24,754 & 13,122 & 37,876 & 24,754 & 13,122 \\
\hline
\end{tabular}

NOTE - The dependent variable is the relative wage rates of blacks. In panel A, relative wages are conditional on five indicators of years of completed education $(0-8,9-11,12,13-15$, and 16+) and a quartic in potential experience. In panel B, relative wages are conditional on five indicators of years of completed education $(0-8,9-11,12,13-15$, and $16+)$, a quartic in potential experience, and occupation fixed effects. Estimates are weighted by sampling weights provided by the Current Population Survey. Standard errors are adjusted for state-year clustering and appear in parentheses. All regressions include state and year fixed effects. The reported number of observations is for blacks only. Details about sample construction are in Appendix Table 2. The sample is limited to the years 1977-1994 due to availability of log new incorporations per capita data. In columns (1), (4), and (7) we include the entire sample. In columns (2), (5), and (8) we include only states with racial bias index below the median. In columns (3), (6), and (9) we include only states with racial bias index above the median. The racial bias index is based on rate of interracial marriages using the 1970 Census of Population. Appendix Table 3 lists the racial bias index for each state. Columns (1)-(3) report Ordinary Least Squares estimates of the impact of log new incorporations per capita on the relative wage rates of blacks. Columns (4)-(9) report Two Stage Least Squares estimates of the impact of log new incorporations per capita on the relative wage rates of blacks. In columns (4)-(6), log new incorporations per capita are instrumented by years since interstate deregulation and years since intrastate deregulation. In columns (7)-(9), log new incorporations per capita are instrumented by dummy variables for each year before and after interstate deregulation and dummy variables for each year before and after intrastate deregulation. The F-test of excluded instruments reports the F-statistic from the first-stage. The OIR test reports the p-value of a J-statistic that test over-identifying restrictions. *, $* *$, and ${ }^{* *}$ indicate significance at the $10 \%, 5 \%$, and $1 \%$ respectively. 
Table 5

THE IMPACT OF LOG NEW INCORPORATIONS ON THE RELATIVE WAGES OF BLACKS: OLS AND 2SLS ESTIMATES LEVINE-LEVKOV-RUBinSTEIN AND CHARLES-GURYAN MEASURES OF RACIAL PREJUDICE

\begin{tabular}{|c|c|c|c|c|c|c|c|c|}
\hline & \multicolumn{4}{|c|}{ OLS } & \multicolumn{4}{|c|}{ 2SLS } \\
\hline & \multicolumn{2}{|c|}{$\begin{array}{c}\text { Racial Bias } \\
\text { Below Median }\end{array}$} & \multicolumn{2}{|c|}{$\begin{array}{c}\text { Racial Bias } \\
\text { Above Median }\end{array}$} & \multicolumn{2}{|c|}{$\begin{array}{c}\text { Racial Bias } \\
\text { Below Median }\end{array}$} & \multicolumn{2}{|c|}{$\begin{array}{c}\text { Racial Bias } \\
\text { Above Median }\end{array}$} \\
\hline & $\begin{array}{c}\text { LLR } \\
(1)\end{array}$ & $\begin{array}{l}\text { CG } \\
(2)\end{array}$ & $\begin{array}{c}\text { LLR } \\
(3)\end{array}$ & $\begin{array}{c}\text { CG } \\
(4)\end{array}$ & $\begin{array}{c}\text { LLR } \\
(5)\end{array}$ & $\begin{array}{c}\text { CG } \\
(6)\end{array}$ & $\begin{array}{c}\text { LLR } \\
(7)\end{array}$ & $\begin{array}{c}\text { CG } \\
(8)\end{array}$ \\
\hline Log new incorporation per capita & $\begin{array}{l}-.029 \\
(.023)\end{array}$ & $\begin{array}{l}-.029 \\
(.030)\end{array}$ & $\begin{array}{l}.124^{* * *} \\
(.037)\end{array}$ & $\begin{array}{c}.039 \\
(.028)\end{array}$ & $\begin{array}{l}-.024 \\
(.071)\end{array}$ & $\begin{array}{l}-.051 \\
(.057)\end{array}$ & $\begin{array}{l}.224^{* * *} \\
(.068)\end{array}$ & $\begin{array}{l}.165^{* *} \\
(.076)\end{array}$ \\
\hline F-test of excluded instruments & & & & & 8.1 & 32.8 & 26.8 & 16.2 \\
\hline OIR test ( $\mathrm{p}$-value) & & & & & .375 & .264 & .259 & .571 \\
\hline Observations & 24,272 & 8,093 & 12,942 & 29,121 & 24,272 & 8,093 & 12,942 & 29,121 \\
\hline
\end{tabular}

NOTE - The dependent variable is the relative wage rates of blacks. Relative wages are conditional on five indicators of years of completed education $(0-8,9-11,12,13-15$, and 16+), a quartic in potential experience, and occupation fixed effects. Estimates are weighted by sampling weights provided by the Current Population Survey. Standard errors are adjusted for state-year clustering and appear in parentheses. All regressions include state and year fixed effects. The reported number of observations is for blacks only. Details about sample construction are in Appendix Table 2. The sample is limited to the years 1977-1994 due to availability of $\log$ new incorporations per capita data. "LLR" stands for the racial bias index and is based on rate of interracial marriages using the 1970 Census of Population. Appendix Table 3 lists the racial bias index for each state. "CG" stands for the marginal racial prejudice which is obtained from Charles and Guryan (2008). In columns (1) and (5) we include only states with racial bias index below the median. In columns (3) and (7) we include only states with racial bias index above the median. In columns (2) and (6) we include only states with marginal racial prejudice below the median. In columns (4) and (8) we include only states with marginal racial prejudice above the median. Columns (1)-(4) report Ordinary Least Squares estimates of the impact of log new incorporations per capita on the relative wage rates of blacks. Columns (5)-(8) report Two Stage Least Squares estimates of the impact of log new incorporations per capita on the relative wage rates of blacks. Log new incorporations per capita are instrumented by dummy variables for each year before and after interstate deregulation and dummy variables for each year before and after intrastate deregulation. The F-test of excluded instruments reports the F-statistic from the first-stage. The OIR test reports the p-value of a Jstatistic that test over-identifying restrictions. ${ }^{*}{ }^{* *}$, and ${ }^{* * *}$ indicate significance at the $10 \%, 5 \%$, and $1 \%$ respectively. 


\section{Table 6}

The Impact of Log NeW Incorporations Per CAPITA On Relative Wage RATES: OLS AND 2SLS Estimates RELATIVE WAGES ARE CONDITIONAL ON EDUCATION, EXPERIENCE, OCCUPATION, AND INDUSTRY

\begin{tabular}{|c|c|c|c|c|c|c|c|c|c|}
\hline & \multicolumn{3}{|c|}{ OLS } & \multicolumn{3}{|c|}{ 2SLS: Linear } & \multicolumn{3}{|c|}{ 2SLS: Non-Parametric } \\
\hline & \multirow{3}{*}{$\begin{array}{c}\text { All } \\
\text { States }\end{array}$} & \multicolumn{2}{|c|}{ Racial Bias Index: } & \multirow{3}{*}{$\begin{array}{c}\text { All } \\
\text { States }\end{array}$} & \multicolumn{2}{|c|}{ Racial Bias Index: } & \multirow{3}{*}{$\begin{array}{c}\text { All } \\
\text { States }\end{array}$} & \multicolumn{2}{|c|}{ Racial Bias Index: } \\
\hline & & Below & Above & & Below & Above & & Below & Above \\
\hline & & Median & Median & & Median & Median & & Median & Median \\
\hline & $(1)$ & $(2)$ & (3) & $(4)$ & (5) & (6) & (7) & (8) & (9) \\
\hline \multirow[t]{2}{*}{ Log new incorporation per capita } & .018 & -.024 & $.123^{* * *}$ & -.012 & .010 & .190 *** & .005 & -.043 & $.172^{* * *}$ \\
\hline & $(.020)$ & $(.022)$ & $(.035)$ & $(.061)$ & $(.070)$ & $(.067)$ & $(.042)$ & $(.048)$ & $(.056)$ \\
\hline F-test of excluded instruments & & & & 21.8 & 8.2 & 26.8 & 3.0 & 2.3 & 113.5 \\
\hline OIR test (p-value) & & & & .316 & .813 & .051 & .814 & .638 & .122 \\
\hline Observations & 37,876 & 24,754 & 13,122 & 37,876 & 24,754 & 13,122 & 37,876 & 24,754 & 13,122 \\
\hline
\end{tabular}

NOTE - The dependent variable is the relative wage rates of blacks. Relative wages are conditional on five indicators of years of completed education (0$8,9-11,12,13-15$, and 16+), a quartic in potential experience, occupation fixed effects, and industry fixed effects. Estimates are weighted by sampling weights provided by the Current Population Survey. Standard errors are adjusted for state-year clustering and appear in parentheses. All regressions include state and year fixed effects. The reported number of observations is for blacks only. Details about sample construction are in Appendix Table 2. The sample is limited to the years 1977-1994 due to availability of log new incorporations per capita data. In columns (1), (4), and (7) we include the entire sample. In columns (2), (5), and (8) we include only states with racial bias index below the median. In columns (3), (6), and (9) we include only states with racial bias index above the median. The racial bias index is based on rate of interracial marriages using the 1970 Census of Population. Appendix Table 3 lists the racial bias index for each state. Columns (1)-(3) report Ordinary Least Squares estimates of the impact of log new incorporations per capita on the relative wage rates of blacks. Columns (4)-(9) report Two Stage Least Squares estimates of the impact of log new incorporations per capita on the relative wage rates of blacks. In columns (4)-(6), log new incorporations per capita are instrumented by years since interstate deregulation and years since intrastate deregulation. In columns (7)-(9), log new incorporations per capita are instrumented by dummy variables for each year before and after interstate deregulation and dummy variables for each year before and after intrastate deregulation. The F-test of excluded instruments reports the F-statistic from the first-stage. The OIR test reports the p-value of a J-statistic that test over-identifying restrictions. * $* *$, and ${ }^{* * *}$ indicate significance at the $10 \%, 5 \%$, and $1 \%$ respectively. 
Table 7

Relative Log Hourly Wages and Annual Working Hours in High Racial Bias States

\begin{tabular}{|c|c|c|c|c|c|c|}
\hline & \multicolumn{4}{|c|}{ Annual Hours } & \multicolumn{2}{|c|}{ Log(Annual Hours) } \\
\hline & All & All & Hours $>0$ & All & All & All \\
\hline & OLS & Tobit & OLS & 2SLS & OLS & 2SLS \\
\hline & $(1)$ & $(2)$ & (3) & $(4)$ & $(5)$ & (6) \\
\hline \multirow[t]{2}{*}{ Projected relative log hourly wage } & $377^{*}$ & $376^{*}$ & $424^{*}$ & & $.658^{* *}$ & \\
\hline & $(223)$ & $(223)$ & $(223)$ & & $(0.285)$ & \\
\hline \multirow[t]{2}{*}{ Log new incorporations per capita } & & & & 59 & & $.271^{* * *}$ \\
\hline & & & & $(105)$ & & $(.106)$ \\
\hline \multicolumn{7}{|l|}{ Instruments: } \\
\hline Years since deregulation & Yes & Yes & Yes & Yes & Yes & Yes \\
\hline Years since deregulation squared & Yes & Yes & Yes & Yes & Yes & Yes \\
\hline F-test of excluded instruments & 21.5 & 21.5 & 21.5 & 21.7 & 21.5 & 21.3 \\
\hline OIR test ( $\mathrm{p}$-value) & .19 & .19 & .19 & .39 & .19 & .49 \\
\hline Observations & 20,556 & 20,556 & 16,951 & 20,556 & 16,951 & 16,951 \\
\hline
\end{tabular}

NOTE - The dependent variable is either hours worked or the log of hours worked. Thus, some specifications include all working-age black males, while others include only working black males. Estimates are weighted by sampling weights provided by the Current Population Survey. Standard errors are adjusted for state-year clustering and appear in parentheses. In regressions (1) - (3) and (4), the standard errors are bootstrapped. All regressions include state and year fixed effects. The analysis excludes states with below the median values of the racial bias index. Data on new incorporations per capita are available for the period 1977-1994. "Years since deregulation" includes both years since interstate deregulation and years since intrastate deregulation. The F-test of excluded instruments reports the F-statistic from the first-stage. The OIR test reports the p-value of a J-statistic that test over-identifying restrictions. ${ }^{*}, * *$, and ${ }^{* * *}$ indicate significance at the $10 \%, 5 \%$, and $1 \%$, respectively. 


\section{Table 8}

BANK DEREgulation AND SELECTION ON OBSERVABLE CHARACTERISTICS

\begin{tabular}{|c|c|c|c|c|c|c|}
\hline & \multicolumn{2}{|c|}{$\begin{array}{c}\text { All } \\
\text { States }\end{array}$} & \multicolumn{2}{|c|}{$\begin{array}{l}\text { Racial Bias Index } \\
\text { Below Median }\end{array}$} & \multicolumn{2}{|c|}{$\begin{array}{l}\text { Racial Bias Index } \\
\text { Above Median }\end{array}$} \\
\hline & (1) & (2) & (3) & (4) & (5) & (6) \\
\hline \multirow[t]{2}{*}{1 if person reports wages } & $.066^{* * *}$ & $.075^{* * *}$ & $.064^{* * *}$ & $.070^{* * *}$ & $.069 * * *$ & $.082^{* * *}$ \\
\hline & $(.003)$ & $(.003)$ & $(.003)$ & $(.004)$ & $(.005)$ & $(.005)$ \\
\hline \multirow[t]{2}{*}{ Interstate } & $-.004^{* * *}$ & & $-.005^{* * *}$ & & -.001 & \\
\hline & $(.001)$ & & $(.001)$ & & $(.003)$ & \\
\hline \multirow[t]{2}{*}{ Interstate $x$ ( 1 if person reports wages) } & $.002^{* * *}$ & & $.002^{* * *}$ & & $.002^{* * *}$ & \\
\hline & $(.000)$ & & $(.000)$ & & $(.000)$ & \\
\hline \multirow[t]{2}{*}{ Intrastate } & & -.001 & & -.001 & & -.000 \\
\hline & & $(.000)$ & & $(.001)$ & & $(.001)$ \\
\hline \multirow[t]{2}{*}{ Intrastate $x$ ( 1 if person reports wages) } & & $.001^{* * *}$ & & $.001^{* * *}$ & & .000 \\
\hline & & $(.000)$ & & $(.000)$ & & $(.000)$ \\
\hline Impact of deregulation on observable skills of black workers & -.002 & .0001 & $-.003^{*}$ & .0003 & .001 & -.0002 \\
\hline $\mathrm{H}_{0}:($ Years since deregulation $) \times(1$ if person reports wages $)=0$ & $(.001)$ & $(.0005)$ & $(.001)$ & $(.0006)$ & $(.002)$ & $(.0008)$ \\
\hline Observations & 116,593 & 116,593 & 77,301 & 77,301 & 39,292 & 39,292 \\
\hline
\end{tabular}

NOTE - The dependent variable is the predicted relative wages of blacks. Relative wages are conditional on five indicators of years of completed education (0-8,

9-11, 12, 13-15, and 16+) and a quartic in potential experience. Estimates are weighted by sampling weights provided by the Current Population Survey.

Standard errors are adjusted for state-year clustering and appear in parentheses. All regressions control for state and year fixed effects. The reported number of observations is for blacks only. Details about sample construction are in Appendix Table 2. The sample is limited to the years 1977-1994 due to availability of log new incorporations per capita data. In columns (1) and (2) we include the entire sample. In columns (3) and (4) we include only states with racial bias index below the median. In columns (5) and (6) we include only states with racial bias index above the median. The racial bias index is based on rate of interracial marriages using the 1970 Census of Population. Appendix Table 3 lists the racial bias index for each state. *, **, and *** indicate significance at the $10 \%$, $5 \%$, and $1 \%$ respectively. 
Appendix Table 1

DATES OF INTRASTATE AND INTERSTATE DEREGULATIONS, BY STATES

\begin{tabular}{|c|c|c|c|c|c|c|c|}
\hline \multirow[b]{2}{*}{ State } & \multirow[b]{2}{*}{ State code } & \multicolumn{2}{|c|}{ Type of deregulation: } & \multirow[b]{2}{*}{ State } & \multirow[b]{2}{*}{ State code } & \multicolumn{2}{|c|}{ Type of deregulation } \\
\hline & & $\begin{array}{l}\text { Intra- } \\
\text { state }\end{array}$ & $\begin{array}{l}\text { Inter- } \\
\text { state }\end{array}$ & & & $\begin{array}{l}\text { Intra- } \\
\text { state }\end{array}$ & $\begin{array}{l}\text { Inter- } \\
\text { state }\end{array}$ \\
\hline Alabama & $\mathrm{AL}$ & 1981 & 1987 & Montana & MT & 1990 & 1993 \\
\hline Alaska & $\mathrm{AK}$ & 1960 & 1982 & Nebraska & $\mathrm{NE}$ & 1985 & 1990 \\
\hline Arizona & $\mathrm{AZ}$ & 1960 & 1986 & Nevada & NV & 1960 & 1985 \\
\hline Arkansas & AR & 1994 & 1989 & New Hampshire & $\mathrm{NH}$ & 1987 & 1987 \\
\hline California & CA & 1960 & 1987 & New Jersey & NJ & 1977 & 1986 \\
\hline Colorado & $\mathrm{CO}$ & 1991 & 1988 & New Mexico & NM & 1991 & 1989 \\
\hline Connecticut & $\mathrm{CT}$ & 1980 & 1983 & New York & NY & 1976 & 1982 \\
\hline District of Columbia & $\mathrm{DC}$ & 1960 & 1985 & North Carolina & $\mathrm{NC}$ & 1960 & 1985 \\
\hline Florida & FL & 1988 & 1985 & North Dakota & ND & 1987 & 1991 \\
\hline Georgia & GA & 1983 & 1985 & Ohio & $\mathrm{OH}$ & 1979 & 1985 \\
\hline Hawaii & $\mathrm{HI}$ & 1986 & 1997 & Oklahoma & OK & 1988 & 1987 \\
\hline Idaho & ID & 1960 & 1985 & Oregon & OR & 1985 & 1986 \\
\hline Illinois & IL & 1988 & 1986 & Pennsylvania & PA & 1982 & 1986 \\
\hline Indiana & IN & 1989 & 1986 & Rhode Island & RI & 1960 & 1984 \\
\hline Iowa & IA & 1999 & 1991 & South Carolina & SC & 1960 & 1986 \\
\hline Kansas & KS & 1987 & 1992 & Tennessee & $\mathrm{TN}$ & 1985 & 1985 \\
\hline Kentucky & KY & 1990 & 1984 & Texas & $\mathrm{TX}$ & 1988 & 1987 \\
\hline Louisiana & LA & 1988 & 1987 & Utah & UT & 1981 & 1984 \\
\hline Maine & $\mathrm{ME}$ & 1975 & 1978 & Vermont & VT & 1970 & 1988 \\
\hline Maryland & MD & 1960 & 1985 & Virginia & VA & 1978 & 1985 \\
\hline Massachusetts & MA & 1984 & 1983 & Washington & WA & 1985 & 1987 \\
\hline Michigan & MI & 1987 & 1986 & West Virginia & WV & 1987 & 1988 \\
\hline Minnesota & $\mathrm{MN}$ & 1993 & 1986 & Wisconsin & WI & 1990 & 1987 \\
\hline Mississippi & MS & 1986 & 1988 & Wyoming & WY & 1988 & 1987 \\
\hline Missouri & $\mathrm{MO}$ & 1990 & 1986 & & & & \\
\hline
\end{tabular}

NOTE - Dates of intrastate and interstate deregulations are taken from Kroszner and Strahan (1999). 


\section{Appendix Table 2}

Civilian adults, not in group quarters, with positive sampling weight and

Excluding:

Observations in Delaware and South Dakota

$3,712,856$

Women

Younger than 18 or older than 65

More than 50 years of potential experience

Main sample:

Whites

Blacks

Wage sample:

All

Whites

NOTE - March Current Population Survey data were obtained from <http://cps.ipums.org/cps/>. We start in Survey year 1977 because that is when the CPS reports information on each person's exact state of residence. The 2007 Survey is the latest Survey available. We exclude Delaware and South Dakota due to large concentration of credit card banks in these two states. The 'wage sample' differs from the 'main sample' in that we drop self-employed and agricultural workers, workers in private household sector, those with wages below the $1^{\text {st }}$ and above the $97^{\text {th }}$ percentile of yearspecific wage distribution of full-time, full-year workers (i.e., those who work at least 50 weeks per year and at least 35 hours per week). Finally, we include in the 'wage sample' only wage and salary workers. 
Appendix Table 3

RACIAL Bias INDEX by STATES, 1970

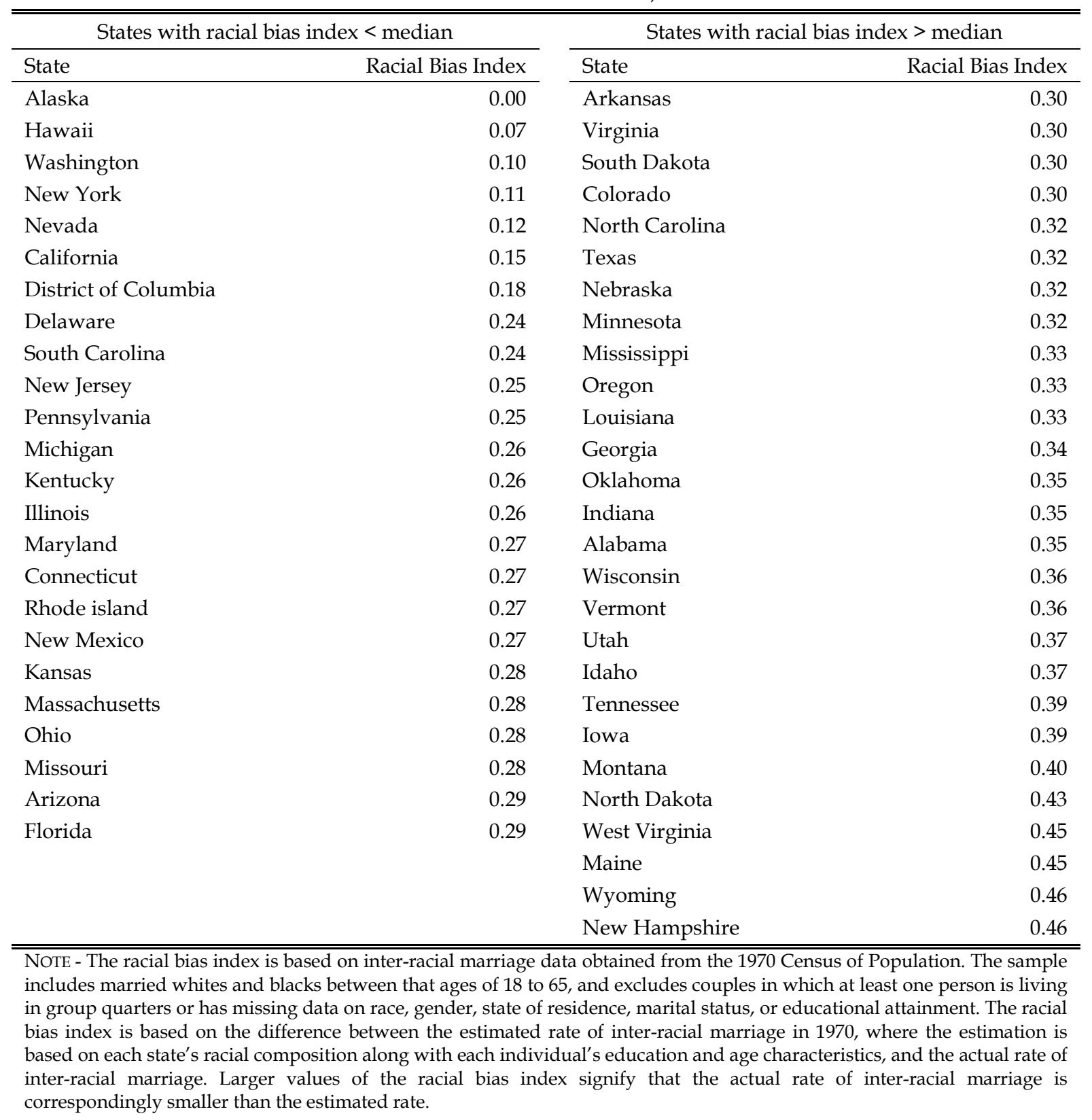

